\title{
CIENCIA Y SOCIEDAD
}

Volumen XXXI, Número 1

Enero-Marzo 2006

\section{ALGUNOS ASPECTOS SOCIOCULTURALES DE LA INMIGRACIÓN HAITIANA HACIA LA REPÚBLICA DOMINICANA \\ Reina Rosario* Jorge Ulloa**}

\section{RESUMEN}

Hace más de una década la realización de la tesis de maestría de uno de los autores de la presente investigación en la universidad de Lomonosov en la antigua URSS significó una primera aproximación a este tema. En ese momento los principales elementos abordados giraron en torno al surgimiento y desarrollo en la isla de Santo Domingo de las dos etnias que actualmente la habitan, además de hacer hincapié en algunos aspectos demográficos, sociales y culturales de la migración haitiana hacia la República Dominicana. Los resultados de ese primer acercamiento se fundamentaron esencialmente en una revisión historiográfica de las relaciones entre la República Dominicana y Haití, así como en el trabajo de campo.

A partir de los años noventa del siglo XX la situación migratoria haitiana ha sufrido importantes cambios, lo que ha implicado que a la luz de las actuales condiciones muchos de los conocimientos generados sobre el tema durante las pasadas décadas hayan sufrido evidentes e importantes transformaciones, en tanto elementos que sólo se vislumbraban como tendencias han alcanzado su plena madurez. Son estos cambios en la situación los que han generado un incentivo para desarrollar este abordaje con sentido longitudinal y comparativo con respecto a los resultados generados anteriormente. Este nuevo análisis permite comparar los rasgos observados décadas atrás a la luz de la realidad socioeconómica actual, así como a partir de los nuevos datos generados por las Ciencias Sociales dominicanas

Para ello se han tomado en cuenta los datos aportados por trabajos de campo llevados a cabo a partir de las asignaturas Antropología Social y Procesos Sociohistóricos dominicanos, del Instituto Tecnológico de Santo Domingo, en dos comunidades con gran incidencia de población inmigrante, el batey de Palavé y la zona conocida como Pequeño Haití.

* Ciencias Sociales, INTEC. Emait: reinar(a)intec.edu.do

** Ciencias Sociales, INTEC. Email: ulloa12cu@yahoo.com 
PALABRAS CLAVES

Etnicidad, Cultura, Identidad, Migración.

\begin{abstract}
More than one decade ago, the thesis of one of the authors of the present rescarch in the University of Lomonosov in the old URSS, meant the first approximation to this topic. At that time the main elements approached revolved around the appearance and development in the island of Santo Domingo of the two ethnic groups that populate it today, emphasizing some demographic. social. and cultural aspects of the Haitian migration to the Dominican Republic. The results of this first approach were essentially based on a historiography review of the relations between the Dominican Republic and Haiti, and on the field research itself.

From the years ninety, of the XXth century, the Haitian migratory situation has suffered important changes. It means that in the actual conditions. a large portion of the generated knowledge about the topic during the past decades, could undergo important and obvious transformations. At the same time. elements that were visualized as tendencies have reached their full level of importance. These changes have created an incentive to develop the present approach in a comparative and extended sense. This new analysis allows the comparison of the characteristics observed for decades as per today's socioeconomical reality. same as for the new data generated by the Dominican Social Sciences.

For this approach, we have been paying attention to the information provided by other field researches on: Social Anthropology and Dominican Sociohistory Processes, made by the "Instituto Tecnológico de Santo Domingo", in two communities in which there is a large incidence of the immigrant population. namely the town of "Palavé" and the zone known as Little Haiti.
\end{abstract}

\title{
KEY WORDS
}

Ethnicity; Culture, Identity, Migration.

\section{Una introducción necesaria}

Hace más de una década una primera incursión en este tema fue motivada por la realización de la tesis de maestría de uno de los autores de la presente investigación en la universidad de Lomonosov en la antigua URSS. En ese momento los principales elementos abordados giraron en torno al surgimiento y desarrollo en la isla de Santo Domingo de las dos etnias que actualmente la habitan, además de hacer hincapié en algunos aspectos demográficos, sociales y culturales de la migración haitiana hacia la República Dominicana. Los resultados de ese primer acercamiento se fundamentaron esencialmente en una revisión historiográfica de las relaciones entre la República Dominicana y Haití, así como en el trabajo de campo. 
A la luz de las actuales condiciones muchos de los resultados obtenidos en ese momento han sufrido evidentes e importantes transformaciones, mientras otros elementos que sólo se vislumbraban como tendencias han alcanzado su plena madurez. Esta situación fue uno de los principales incentivos para generar un nuevo acercamiento al tema que le otorgara un sentido longitudinal a la investigación anteriormente desarrollada, en tanto su objetivo central sería comparar los principales resultados obtenidos una década atrás con los nuevos datos generados por las Ciencias Sociales dominicanas.

En el desarrollo de la presente investigación, al igual que enl la primera, el análisis historiográfico, ahora con una perspectiva comparativa actualizada, asume una importancia trascendental para comprender los intríngulis de un fenómeno que ha sido escasamente abordado desde la perspectiva antropológica. También se han asumido los datos aportados por trabajos de campo llevados a cabo a partir de las asignaturas Antropología Social y Procesos Sociohistóricos Dominicanos del Instituto Tecnológico de Santo Domingo, además de la información estadística y teórica recientemente aportada por las obras La nueva Inmigración haitiana' y Encuesta sobre inmigrantes haitianos en República Dominicanc ${ }^{2}$, las que pueden considerarse estudios actualizados sobre el tema. donde se combinan la perspectiva sociológica y antropológica para adentrarse en los caminos de las transformaciones culturales y de la identidad de los inmigrantes.

Sobre la base de todo lo anterior las principales conclusiones y datos obtenidos hace más de una década en la primera aproximación a la temática constituyen el punto de partida esencial para el presente estudio, por lo que nos parece pertinente reproducir algunos de los aspectos fundamentalés que fueron observados en ese momento (Rosario, 1989):

1. Las relaciones entre Haití y la República Dominicana, esencialmente complicadas y marcadas por la confrontación, han influido en el reforzamiento de las diferencias étnicas y en la visión opuesta que prevalece respecto a los inmigrantes haitianos.

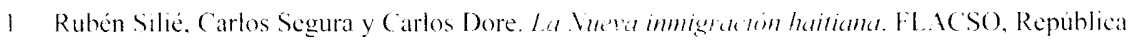
Dominicana, $200(12$.

2 Encuesta sobre inmigrantes haitianos en Republica Dominicana publicada por la OIM y la FLA(SO) en el 2004

3 Rosario, Reina "Algunos aspectos etnodemográticos de la migracion hatiana a Republica Dominicana". Trabajo presentado para aspirar al grado de maesuria en la l iniversidad de lomonosor, mecanuscrito ilustrado. Moscu, 1989. 
2. La utilización de mano de obra haitiana estaba fundamentalmente vinculada a la producción de azúcar en la República Dominicana. lo que conllevaba a un fenómeno de paralización tecnológica en esta área de la cconomía, pues en lugar de modernizar la producción como forma de abaratar los costos resultaba más económico utilizar esta mano de obra. Esto desvirtuaba la propia esencia capitalista de la producción.

3. La fuerza de trabajo haitiana y el carácter ilegal en su mayor parte influye en la reducción del nivel de vida de los trabajadores dominicanos, pues estos sufren la competencia de una mano de obra que reduce al máximo los costos a los empleadores. Esta situación es un factor que agudiza las contradicciones interétnicas.

4. El principal flujo migratorio haitiano estaba remitido a la región sureste de la República Dominicana, en ello influía la ubicación en esta zona de los principales ingenios, lo que incluso provocaba un flujo migratorio desde otras partes del país hacia esta región

5. La introducción de prejuicios raciales con respecto a la migración haitiana podia considerarse un arma ideológica de las clases gobernantes dominicanas. Dichos prejuicios han dado lugar a falsas valoraciones del problema migratorio haitiano. Estas evaluaciones estuvieron influidas por los ideólogos del régimen trujillista. quienes plantearon que la migración haitiana reunía todas las características negroides susceptibles para haitianizar a la población dominicana, de ahí que fomentaran el rechazo no sólo social sino también racial hacia esta inmigración.

6. Las clases oligárquicas dominicanas reconocían la existencia de dos clases de haitianos, la clase alta y afrancesada cuya aceptación era evidente, y una clase baja e inferior que supuestamente representaba un conglomerado social sin ningún ideal. Dicha distinción subrayaba cierta solidaridad o respeto hacia la oligarquía haitiana y a su vez un desprecio hacia la mayoría de su población. cuya inferioridad se intentaba justificar tanto en términos raciales como socioculturales utilizando la pantalla de la diferencia cultural.

7. Los prejuicios creados sobre las expresiones culturales de los emigrados y las traumáticas relaciones históricas entre ambos países han influido en la segregación territorial de la población emigrante.

8. Toda una corriente de pensadores e historiadores dominicanos han elaborado la tesis de la inferioridad cultural haitiana, tesis que han 
ido penetrando en la conciencia social de los dominicanos y ha condicionado su estructura mental y sus reflejos sociales frente a los inmigrantes. Los estereotipos fundamentales en este caso presentan al haitiano como el africano, utilizando este término en su acepción peyorativa como sinónimo de bárbaro, mientras el dominicano aparece como occidentalizado.

9. Las repercusiones en el plano religioso de los estereotipos creados presentan al inmigrante haitiano sumido en un océano de animismo y de creencias primitivas en las que no puede existir nada en común con cl catolicismo prevaleciente en la religiosidad popular dominicana.

10. La migración de braceros temporales haitianos no establecía una influencia equilibrada en las relaciones entre las dos culturas. Este tipo de migración hacia la República Dominicana significaba un grupo de personas que sistemáticamente se trasladaban de una región del país a otra por lo que su interrelación cultural no era tan intensa como la de los braceros que se establecían en el país, sobre todo en la región próxima a la frontera.

11. Los inmigrantes haitianos conservaban muchas de las características culturales específicas, en primer lugar la lengua, la religión así como la ropa femenina tradicional y la ropa dominguera masculina, las comidas, y los elementos tradicionales de sus viviendas.

12. Es característico en los inmigrantes el bilingüismo, creole-español, resultado del contacto continuo con la sociedad dominicana.

13. En la esfera religiosa la influencia mutua es fuerte por lo que se vislumbraba la formación de nuevas expresiones religiosas que se distinguían tanto del catolicismo de los dominicanos como de la religión vodú de los haitianos. Sin embargo, la mayor parte de los haitianos que arribaban a la República Dominicana no renegaban del culto vodú, aunque incorporaban muchos elementos de los ritos católicos a su religiosidad, de este modo era posible distinguir a los inmigrantes haitianos y a sus descendientes en este aspecto.

14. Las condiciones ecológicas similares para las etnias que comparten la isla influía en la existencia de similitudes en cuanto a las preferencias alimentarias, las principales diferencias se localizaban en la forma de preparación de las comidas.

En el caso de los platos ceremoniales la comida voduista, que es una exclusividad haitiana, se preparaba con frecuencia entre los 
inmigrantes y sus expresiones más significativas eran el llamado plato divisional, la mesa divisional y la higuera de los guedes.

15. La emigración haitiana había provocado cambios étnicos culturales en la República Dominicana, cambios que no sólo eran poco conocidos sino también poco reconocidos por la mayor parte de la población. Estos cambios eran más perceptibles en regiones donde era intensa la convivencia y el contacto entre ambas culturas.

16. Debido al carácter continuo de la inmigración haitiana hacia la República Dominicana y la intensidad de las influencias entre ambas etnias era factible la procreación en algunas regiones, especialmente en las zonas fronterizas, de un nuevo grupo étnico con características propias y diferentes.

\section{Migración Haitiana e Historia}

La situación del inmigrante haitiano en la República Dominicana no puede verse desligada de la perspectiva histórica que muestra a la misma matizada por los diferentes momentos de crisis política y económica por la que han atravesado ambas naciones.

La primera oleada migratoria masiva desde Haití hacia República Dominicana se produjo después de finalizada la guerra entre ambos países (1844), cuando una gran cantidad de campesinos haitianos cruzó la frontera con el propósito de establecerse en la región este de la isla. Desde esa época, y en especial con el advenimiento al poder del presidente Francisco Gregorio Billini en 1885, se manifestó cierta preocupación por el fenómeno. preocupación que se acrecentaba debido a la ausencia de una demarcación clara en cuanto a los límites fronterizos.

En 1915 se produjo un segundo momento de gran expansión demográfica haitiana (Rosario, 1989) hacia la República Dominicana, el primero del siglo XX, fenómeno que se encuentra estrechamente relacionado con la invasión de tropas norteamericanas a ese país en este año, lo que provocó un colapso de la economía campesina ${ }^{4}$ u un éxodo masivo de trabajado-

4 La ocupación norteamericana de Haiti entre sus propósitos tenia el de convertir la region en un gran emporio de producción de azúcar. Factores de orden externo e interno hicieron fracasar este objetivo y a su ves fueron un estímulo para la propia migración. Entre ellos cabe destacar los enfrentamientos entre rebeldes haitianos y las fuerzas de ocupacion norteamericana (1917-1920) y la expropiación de la tierra del campesinado haitiano a favor del capital norteamericano, todo esto provocaria la destrucción sistemática de la economía tradicional local. 
res haitianos. A esto debe sumársele las posibilidades de oferta laboral en República Dominicana para ese momento ${ }^{5}$.

Fue fundamentalmente a partir de la política de "dominicanización" planteada por el régimen Trujillista, y justificada ideológicamente por un conjunto de intelectuales adeptos al régimen, que dentro de los problemas fundamentales suscitados por la migración haitiana hacia la República Dominicana la relación entre migración y nacionalidad se asumió como uno de los principales centros del debate teórico, político y jurídico, lo que ha suscitado no pocos desacuerdos y ambigüedades. Situación sobre la que también pesa la indefinición del estatus legal de los inmigrantes haitianos y de la gran mayoría de sus descendientes.

La migración haitiana en esta etapa tuvo consecuencias funestas, pues terminó con el genocidio de miles de haitianos a lo largo de la frontera en 1937, hecho que además contribuyó a empañar aún más la relación entre ambos países. La situación de ilegalidad de la mayoría de los braceros. lo cual contradecía las leyes migratorias dominicanas de la época, pero sobre todo el espíritu de discriminación racial presente en ellas, provocó que en su mayor parte las contrataciones de trabajadores en ese período se produjeran de manera ilegal, y no fue hasta la década del 50 y el 60 del siglo pasado (Rosario, 1989) cuando el estado dominicano y haitiano establecieron ciertas bases jurídicas para contrataciones masivas de braceros, sobre todo vinculadas a los períodos de zafras azucareras

A partir de la década de los ochenta el número de braceros contratados para ese fin se redujo considerablemente debido a cierto colapso de la industria azucarera dominicana, por otro lado las relaciones bilaterales entre ambos países se vieron empañadas una vez más, debido a que el sector político haitiano que accedió al poder en 1991 acusó a la República Dominicana en las Naciones Unidas, al considerar como una nueva forma de esclavitud las contrataciones masivas. En junio de 1991 el entonces presidente Joaquín Balaguer en respuesta a ese hecho decretó la deportación de menores y ancianos haitianos que se encontraran en territorio dominicano.

5 Un factor importante y de gran influencia fue el desarrollo de la industria azucarera en la República Dominicana durante la segunda década del siglo XX. La demanda de mano de obra para laborar en esta industria y su estimulo a la migración tambien se percibio como una forma de atenuar las tensiones internas en Haití. En muchos casos esta migracion se manejaba como una salida temporal que garantizaha mano de obra barata en la nueva industria azucarera, básicamente de capital norteamericano, en estos paises. 
Para 1996 la cuestión de los braceros volvió a relucir, y el 10 de diciembre de ese año se efectuó un acuerdo entre ambos gobiernos para la contratación, pero en este caso mediante convenios individuales.

En sentido general cabe decir que la migración haitiana hacia República Dominicana se encuentra íntimamente relacionada desde sus inicios con la oferta laboral y el desequilibrio en el desarrollo capitalista en ambas regiones de la isla. además de que la misma refleja o reproduce con cierta fidelidad las propias características de la población inmigrante en su país de origen. Los campesinos tienden a insertarse en el sector agrícola o agropecuario, mientras los que llegan directamente desde los centros urbanos buscan insertarse en el sector de la construcción o del comercio informal. Es esta última clase de inmigrantes la más común en los momentos actuales, por lo que la situación con respecto a años atrás se ha transformado con fuertes implicaciones no sólo en el plano económico sino en la propia estrategia de identidad étnica del grupo inmigrante.

\section{Una nueva situación}

El tono y las características de la emigración haitiana actual han cambiado (Ghasmann Bissainthe, 2002) e incluye personas que pueden haber experimentado un proceso de migración hacia zonas urbanas dentro del propio Haití. Se trata de un tipo diferente de emigrante que abarca una mayor variedad de sectores sociales, esto ha provocado que la dinámi-. ca migratoria no sólo se haya transformado sino que se ha vuelto más compleja. Casi todos los nuevos inmigrantes están vinculados a negocios informales y presentan niveles educativos básicos o poseen algún tipo de documentación de identidad haitiana. En otras palabras han aumentado los estereotipos laborales atribuidos a los obreros haitianos.

Las investigaciones recientes sobre la actual migración haitiana hacia República Dominicana (Silié. et al, 2002) también señalan como un elemento distintivo la informalidad de la misma, así como la informalidad en la asimilación por parte de la sociedad dominicana. Sin embargo, según estos propios estudios esta situación con respecto a años anteriores también se ha transformado, y los trabajadores agrícolas, principalmente vinculados a la producción azucarera, han dejado de ser mayoría dentro de los inmigrantes en relación con los que se dedican a otras actividades como la construcción, el turismo, las obras públicas y el comercio informal. 
Esta irregularidad constante dentro de la nueva población migratoria, no sólo ha acentuado sus posibilidades de explotación, sino que además ha generado una especie de etnización de la mano de obra dentro de los sectores económicos en los que actualmente tiene mayor incidencia, confiriéndole un lugar específico a partir de los estereotipos y las actitudes discriminatorias existentes.

El desarrollo de un sistema de redes familiares y parentales también ha asumido mayor peso dentro la actual migración haitiana, y en este caso es determinante para definir el lugar o la región donde van a laborar quienes emigran, además del tipo de trabajo al cual van a dedicarse. Las redes pueden explicar en parte porque un emigrante va hacia una zona determinada de la República Dominicana.

Los cambios en la nueva migración haitiana (Silié, et al, 2002) también están influidos por el sistema de contratación, hoy la contratación no se realiza colectivamente como solía hacerse con los braceros azucareros, sino que se realiza de manera individual, y aunque no tiene exactamente un carácter formal, las condiciones del inmigrante para negociar la misma le confieren mayores posibilidades en tanto la persona es libre de moverse a otras áreas de producción o servicios. En otras palabras los inmigrantes pueden ocupar nuevos espacios sociales lo cual incide en su propia decisión de perpetuar la estancia en el territorio dominicano.

Lo anterior ha contribuido a que la relación interétnica entre dominicanos y haitianos se haga más intensa en tanto los nuevos migrantes ya no se dirigen hacia enclaves aislados y rurales, sino que su propia inserción en el mundo laboral según las normas que este impone provocan o generan una relación social cotidiana más directa con los dominicanos/as, además de agregarle una mayor capacidad y movilidad determinadas por las propias ofertas de ese mercado (neolocalidad).

En sentido general es el propio mercado de trabajo dominicano el que dicta las nuevas formas de inserción laboral de los inmigrantes haitianos, los que mayormente ocupan segmentos que demandan menos calificación y mayor esfuerzo físico, además de aquellos donde la supervisión oficial parece ser más débil.

La mayoría de los inmigrantes son contratados de manera informal, es decir sin la existencia de contratos escritos, lo cual permite a sus empleadores esquivar determinadas obligaciones y contribuciones como las correspondientes a la seguridad social, además de limitar o anular sus derechos a otros beneficios que otorgan las leyes laborales. Esta situación también anu- 
la los derechos de los inmigrantes a reclamar o integrarse en organizaciones con este fin, como las organizaciones sindicales. En la mayoría de los casos su situación migratoria irregular los coloca a merced de sus empleadores, quienes no solo se aprovechan de esto para evadir las obligaciones ya mencionadas, sino también para sobre explotar esta fuerza de trabajo y disminuir sus costos productivos a partir del pago de bajos salarios.

Desde el punto de vista del género la proporción de mujeres entre los nuevos inmigrantes ${ }^{6}$ tiende a ser mayor, y se percibe un contacto mucho más fluido con su país de origen, lo cual se facilita por la existencia de mayores medios de comunicación. Esta situación también contribuye al mayor dinamismo del flujo migratorio, exhibiéndose un cambio constante de la población que muchas veces asume un carácter temporal ${ }^{7}$, sin embargo la ilegalidad de la misma continúa siendo una nota distintiva por lo que es muy difícil calcular el período de estadía o el flujo regresivo.

En el caso de la inmigración femenina también es importante señalar que a diferencias de momentos anteriores, donde las mujeres haitianas básicamente emigraban para complementar sobre todo en las labores domésticas la estancia de la población masculina, en esto momentos sus motivaciones y actividades han cambiado insertándose directamente en el mercado de trabajo. Estudios recientes en ese sentido (Wooding y Mosely, $2004: 63)^{8}$ señalan una nueva categoría de mujeres migrantes, las comerciantes en pequeña escala, las que viven en la República Dominicana por razones de sus trabajo pero que constantemente viajan entre los dos países

6 En los momentos actuales se observa una mayor presencia de mujeres entre los inmigrantes, este fenómeno se encuentra determinado en parte por el hecho de que no es una migración hacia zonas rurales y vinculada a determinadas actividades económicas o labores agricolas, generalmente asociada al trabajo masculino sino que se trata de una migración en su mayoria hacia zonas urbanas que se vincula a las actividades informales de todo tipo, dentro de ellas el empleo femenino parece remitirse sobre todo al comercio informal y al trabajo doméstico. Este último es un factor importante en cuanto a la convivencia cultural e influencia étnica en varios renglones sobre todo alimenticio, religioso y lingüistico.

7 Según una Encuesta sobre inmigrantes hatianos en República Dominicana publicada por la OIM y la FLACSO en el 2004, p16. Los inmigrantes viajan a su pais con la frecuencia que les impone la necesidad de llevar recursos a sus familiares o por la falta temporal de trabajo. En este caso se hace notar la cercanía del país emisor de la migración asi como por las eventualidades que se produzcan en el mercado de trabajo.

8 Bridget Wooding y Richard Mosely. Inmigrantes haitianos y dominicanos de ascendencia hatiana en la Repriblica Dominicana. Publicación de la Cooperación Internacional para el Desarrollo (CID) y el Servicio jesuita a Refugiados y Migrantes, Santo Domingo, 2004 
para comprar y vender mercancías. En su mayoría. según este propio estudio. las mujeres migrantes se encuentran en la agricultura, particularmente en los tiempos de cosecha. en el servicio doméstico o en las actividades comerciales. Con respecto a esta última actividad su perfil se ha diversificado y va desde la venta de ropas, alimentos, o productos agrícolas

Por último es bueno señalar que algunos de los inmigrantes de más reciente ingreso a República Dominicana llegan con el objetivo de regresar en un algún momento, lo cual los presenta en un perfil de transmigrantes. y aunque muchos de ellos no regresen pueden viajar a su país con cierta facilidad una vez que han adquirido los medios necesarios para pagar sus gastos de retorno.

\section{El renacimiento de los estereotipos culturales e ideológicos sobre la migración haitiana}

Las nuevas características de la migración haitiana también se encuentran acompañadas del renacimiento de los estereotipos de carácter cultural e histórico sobre la "amenaza haitiana" para la República Dominicana, los que como se ha expresado anteriormente están esencialmente basados en construcciones ideológicas cuyos orígenes fundamentales deben buscarse en la era de Trujillo". Estas construcciones inciden en que el problema migratorio se asuma no sólo como esto, sino como el problema haitiano. es decir como una nueva estrategia para penetrar el territorio dominicano y repetir las invasiones llevadas a cabo en el siglo XIX. En ese sentido la política gestada por los ideólogos del trujillismo pueden considerarse la expresión prístina de las ideas sobre una reevaluación o redefinición de la nacionalidad dominicana, que constantemente se define en crisis o en inminente peligro ante el empuje haitiano.

La asimilación de ese sentimiento de crisis y amenaza constante a la nacionalidad dominicana es congruente a su vez con un fomento de los rencores y el repudio a la cultura popular haitiana, y a su vez con la exaltación

9 Mediante la ley No 597 del 31 de octubre de 1933 Trujillo intentó dominicanizar el corte de caña y obligar a empresas agricolas a utilizar un minimo de $70 \%$ de mano de obra nativa. Sin embargo esto no resultó por la presión de los agroexportaderes norteamericanos que se vieron amenazados por la carencia de mano de obra haitiana en la producción azucarera, esto incentivo además la importación ilegal de miles de braceros en la década de los 30 sin el permiso del gobicrno dominicano 
en el pueblo dominicano de un sentimiento de hispanidad identificado con una supuesta dominicanidad, sentimiento configurado como antítesis de la haitianidad y asumido como tabla de salvación para la nación dominicana. Se trata por tanto de una definición o expresión de la dominicanidad que cobra una dimensión anti-haitiana en su propia afirmación del concepto de nación -estado, y a su vez estimula la creación de estereotipos sociales hacia el inmigrante basados en factores ideológicos, políticos y culturales. En esencia esa dominicanidad se asume como una especie de barrera cultural, como la mejor forma de preservase así misma y a los valores de la hispanidad trasnochada ante la amenaza de un pueblo de fuerte ascendencia africana.

La última de éstas afirmaciones entroncan entonces con una percepción estrecha de la identidad nacional. en tanto conservar la identidad nacional significara evitar todo riesgo de contaminación racial" ${ }^{10}$ influencia cultural de otros pueblos, en particular el haitiano, dentro de la mayoría poblacional. Por otro lado se trata de una supuesta identidad, que en su expresión extrema podría asumirse como algo estrictamente racial". donde

10 Lna investigación realizada por el Servicio Jesuita de Refugiados sobre la actitud racial en la Republica Dominicana expone de manera clara la manera en que incide el racismo y la intolerancia en las relaciones sociales en nuestra sociedad. Fn este estudio se identifica el racismo existente en los ámbitos de socialización de los dominicanos y dominicanas además de referirse cualitativamente a las actitudes cotidianas generadas en el sistema escolar a partir del análisis del curriculo. los programas, las textos, los docentes, y los estudiantes. Por otro lado se aborda como influyen las actitudes racistas en la elección de pareja para el matrimonio, además de las manifestaciones racista dentro de la iglesia. Según este estudio, el $86 \%$ de las personas representantes de las instituciones educativas entrevistadas cree que la sociedad dominicana es racista y que este racisme se expresa en insultos, maltratos verbal, humillacion e injusticia contra las personas negras. Un $26 \%$ de los entrevistados manifiestas que las actitudes racistas tambien se expresan en el rechazo de las personas por el color de la piel, mientras el $(22 \%)$ lo obsersa a tras es de la resistencia a aceptar la negritud como valor. Para mayor información ver: La Actitud Racial en la Repuiblice Dominicanca. Publicación del Servicio Jesuita de Refugiados y Migrantes (SJRM), Santo Domingo. Republica Dominicana, Octubre 2004

11 La posicion opuesta a esta apreciación puede fundamentarse a partir de las investigaciones del historiador cubano Jorge tharra, quien en su articulo "El despertar de la conciencia nacional en (uba, Santo Domingo y Puerto Rico". Revista del Caribé No. 42. Casa del Caribe. Santiago do (uba, 2003, p 26-29 analiza como en el Santo Domingo espanol tempranamente se créo una oligarquía hirracial que detentaba el poder. mientras en ('uba y Puerto Rico los criollos blancos so arrogaban todas las facultades y prerrogativas a partir de una segregación mucho más acentuada entre blancos y negros. El análisis de Ibarra deja claro como el mulataje en el Santo Domingo español fue intenso tempranamente, lo que constituyó un factor que condujo a la tema de conciencia sobre la pertenencia a un origen y destino histórico comunes entre los deminicanos con mucha anterioridad a los cubanos y puertoricuenos. Este sentido de identidad cultural e historia 
el color de la piel de un individuo constituye un elemento sine-qua non de su expresión'2 cultural.

Una caracterización hasta cierto punto clara de este fenómeno nos la remite la obra del etnógrafo haitiano Jean Price Mars, en tanto la posición podría identificarse con lo que él define como "bovarismo racial" ${ }^{* 13}$, en este caso sostenido sobre argumentaciones teóricas que intentan separar por contraste racial las dos etnias que comparten la isla, la haitianidad y la hispanidad. Esta última según esas ideas no necesitaría demostración puesto que dominicanidad e hispanidad se conciben como una misma cosa. La identidad dominicana entonces se intenta manejar, se construye, como ya hemos expresado, sobre la base de la deculturación de la identidad haitiana, lo que se expresa claramente en la obra de Manuel Arturo Peña Batlle al exponer las supuestas carencias que han impedido concretar la identidad haitiana.

Refiere Peña Batlle:

Esa es una sociedad sin historia (...) sin antecedentes tradicionales, sin punto de partida y sin raíces espirituales(...) no evolucionó hacia ninguna forma de cultura (...) no se hizo visible ni siquiera una sola manifestación de cultura (...) lo que propiamente podría llamarse un nivel infra-cultural (...) no alcanzó ni siquiera la expresión de un idioma que le sirviera de instrumento a sus ideas ${ }^{1+}$

constituyó el paso previo a una toma de conciencia nacional, y fue un paso importante para diferenciar las culturas antillanas de su matriz cultural hispánica. En palabras de Ibarra, mientras en otras sociedades del Nuevo Mundo el gentilicio criollo sólo era destinado a los blancos en Santo Domingo era aplicado a todos los habitantes de la isla, es por ello que aunque cualquier concepto de identidad estrictamente racial es totalmente inaceptable en el caso dominicano es aún menos viable.

12 Las prácticas racistas contra los inmigrantes haitianos esta muy bien definida por el Dr. Rubén Silié en su artículo "Aspectos socio-históricos sobre la inmigración haitiana República Dominicana", publicado en la revista general de la Universidad Nacional Pedro Henriques Ureña. EneroDiciembre, 1996, p.35. En dicho artículo ell Dr. Silé expresa:

La práctica racista contra los nacionales haitianos en República Dominicana, entre otras razones. debido a las viejas confrontaciones nacionalistas de los años de las luchas independentistas. contribuye a generar reacciones que siendo estimuladas en el contexto de los requerimientos de mano de obra barata, pasan fácilmente al plano de la defensa de la identidad nacional, e ideológicamente se asume el enfrentamiento en los términos propios de un conflicto racial, tratando de camuflar los aspectos reales impuestos por la necesidad del capital y que hacen propicia la inmigración

13 Jean Price Mars en Asi hablo el tio. Serie Literatura caribeña. Colección la otra orilla, Editora Manatí, Santo Domingo, 2000. Este autor define como bovarismo racial la pretensión de blancura. y el término viene de la novela de Gustave Flaubert Madame Bovary en la que su protagonista Emma Bovary vivia turbada por una idea de sí misma que era un autoengaño.

14 Apud. Andrés L Mateo. Prólogo a la obra de Jean Price Mars en Asi habló el tio. Serie Literatura caribeña. Coleccion la otra orilla, Editora Manati, Santo Domingo, 2000. 
Son los ecos de esta posición enajenante, de ese bovarismo, lo que supuestamente le otorga el derecho a algunos dominicanos para eludir cualquier forma de mestizaje con la cultura haitiana, lo que de hecho implica su propia autonegación, en tanto intentan restituirse en una especie de otredad desconocida, creyendo ser lo que realmente no son.

Una de las expresiones más reciente de esa postura se percibe en la obra de Manuel Núñez El ocaso e la Nación Dominicana ${ }^{15}$. Para este autor la migración haitiana hacia República Dominicana se encuentra en consonancia con un nuevo propósito de colonización, con la imposición de lo que él denomina "la dictadura del débil", se trata de un combate en todos los frentes, de una política única y coherente para fundar una minoría haitiana en la República Dominicana.

El análisis a fondo de los principales puntos de sostén de esta obra arrojan por tanto una versión actualizada de los principales argumentos asumidos por los más ilustres ideólogos de la nacionalidad excluyente. En ese sentido es pertinente exponerlos en tanto constituyen una nueva versión ideológica de ese nacionalismo anquilosado.

El Ocaso de la nación Dominicana no es una obra que se queda en la superficie del prejuicio o en la reducción del tema a un asunto moral. La dimensión del problema es vista como un asunto político de extremo cuidado y para ello se toman en cuenta hechos, acontecimientos y elementos de orden histórico, geográfico, territorial ecológicos vinculados a los procesos de conformación de ambas naciones. A partir de estos elementos se inicia lo que el autor denomina "un combate por esclarecer las consecuencias que para el futuro del país tiene el repertorio de interpretaciones históricas vigentes y los cambios culturales y de población, que quiebran la estructura de la mentalidad y cuya copiosa influencia fracturan el torso nacional" (Núñez, 2001: XXII).

En El Ocaso de la Nación Dominicana hay un componente chovinista acentuado, chovinismo que tiene como blanco esencial la cultura haitiana y que se fundamenta en datos y hechos históricos, en especial relacionados con la invasión haitiana, en este caso todo gira en torno a la dicotomía entre la formación y el ideal de pueblo, este último con un sustento esencial

15 Manuel Núnez. El ocaso de la Nación dominicana. Editora Letra gráfica, Santo Domingo, República Dominicana, 2001. 
cultural, y la formación del estado-nación. En ese sentido la lucha por la independencia del pueblo dominicano no obedeció, según Núñez, a la necesidad de surgir o de configurarse como nación sino ante la amenaza de ser asimilado culturalmente por la naciente República haitianatt.

En la perspectiva histórica de este autor la independencia dominicana se genera estrictamente por razones de índole cultural (Núñez, 202 pags: 29, 33-37) por superar la opresión cultural o las amenazas de absorción de un pueblo que supuestamente es culturalmente inferior, que aún no exhibe, o en el aún no ha fraguado la unidad cultural que tempranamente se había formado para el caso dominicano. Lo cual no deja de ser una paradoja.

El problema o los problemas generados por la migración haitiana son percibidos como en una especie de cadena que le confieren una dimensión diferente en cada aspecto abordado por el autor. así la migración del campo a la ciudad en República Dominicana, la migración de dominicanos hacia el exterior, el reflejo de los temas y elementos africanos en la artesanía y el arte dominicano, la presencia del vodú y el gagá en la religiosidad popular dominicana, la degradación medioambiental en el país entre otros, son el resultado de los efectos directos de este problema migratorio

En el aspecto racial el reconocimiento de la negritud y los aportes africanos en la cultura dominicana para Manuel Núñez son un sinónimo de haitianismo o pro haitianismo, de fomento de peligro hacia la nación, lo cual implica cierto racismo escondido en lo más hondo de sus formulaciones, racismo que a su vez reproduce la fórmula donde Haití es igual a negro ${ }^{17}$.

A partir de aquí subyace entonces el siguiente planteamiento:

16 Para Manuel Núnè. el ejemplo clasico de esto es el nacimiento de un ideal ancxionista antes del surgimiento de la propia Republica Dominicana o de su propio provecto independentista (Nuney. 2002: Pag. 12.538). Por esta misma linca toda la historia dominicina, o por lo menos sus hechos más y trascendentales. está generada por el fantasma de la hat tandad, incluido parte del propio sentimiento anexionista, en tanto la anexion a Espana proclamada por el general Pedro Santana en 1801 es parte de una estrategia para evitar ser tragados por la cultura hatiana. Desde estas perspectivas to que Manuel Nünez denomina "( Kaso" es caracteristico o es inherente a la propia fragua o nacimiento de la nacion dominicana.

17 Segun este autor los esluerzos para dar a conocer los valores africanos y la presencia de valores haitianos dentro de un sincretisno dominicano son una clatudicición de los principios yote nos fundan como nacion, ante una ceguera que oculta las zarpas de las que se bencficia copiosamente de nuestra tragedia, y de aquellos que, tras al mascaron de proa de una detensa de estos indocumentados. se aprestan a quebrar el estado de derecho del pais. Manuel Nunez. El ocaso é la Vacion Dominicama. Pag 63 
Los estudios que nos descubran el sincretismo dominicano con la cultura haitiana son peligrosos y nos desnacionalizan. En otras palabras es necesario ignorar aquello que supuestamente nos avergüenza. cuando en realidad no tenemos porque avergonzarnos.

En resumen, podríamos plantear que la supuesta solución al problema no está en el rechazo o en la negación al estudio y fortalecimiento de los valores culturales de origen africano o en la exaltación de valores dominicanos a partir de un etnocentrismo enfermizo contra el haitiano, que además deja abierta la puerta a otros valores que quizás sean un peligro mayor en un proceso deculturador. La solución no se encuentra en la justificación de la incapacidad dominicana o en la justificación de los prejuicios. la solución no está en presentar a la cultura dominicana como una víctima de los desenfrenados apetitos haitianos por imponerse cultural y demográficamente, lo que reproduce en otro contexto y dimensión el llamado "miedo al negro" creado por las economías plantacionistas caribeñas en el siglo XIX. En ese caso al haitiano se le discrimina y a la vez se le teme por deculturador y porque representa la influencia de una nacionalidad supuestamente asumida bajo un concepto racial.

\section{Los criterios sobre una identidad dominicana dinámica}

La tendencia radicalmente opuesta a la posición esgrimida por El ocaso de la nación Dominicana, aunque no es exactamente nueva ha alcanzado expresiones más claras y concretas en los últimos tiempos. en su mayoría estas expresiones han surgido como una respuesta crítica a la posición anteriormente descrita.

El análisis en profundidad de la manera en que se han abordado conceptos tan importantes como identidad, cultura, nacionalismo a lo largo de la historia Dominicana, o la contribución, ya sea empírica o teórica, a la reformulación de estos conceptos ha sido la nota distintiva del resurgir de esta tendencia.

El resumen gencral de los aspectos más relevantes planteados de manera crítica dentro de ella incluye elementos como los siguientes ${ }^{1 \times}$ :

Ix Jom proncipales elementiss tecrieos que han definido y definen esta tendencia son palpables y han sido resumidos de las obras de Odalis (j Pérez. Nacionalismo y ( Ultura en Republica Dominicana. Editora Matnati, Santo Domingo, Republica Dominicana. 2003 y La ldeologgia Rota 
a) El concepto de identidad ha sido manipulado por el prejuicio de haitianofobia y africanofobia. Una buena parte del pensamiento dominicano del siglo XIX y del XX se ha hundido en estos prejuicios, lo que ha obstaculizado el propio desarrollo cultural y social de la República Dominicana. En la actualidad esta corriente asume una imagen frágil y mezquina de la identidad. sin un análisis real a la luz de los nuevos fenómenos y del contexto social dominicano.

La manipulación de la identidad desde esta perspectiva, tiende a presentarse como un ideal de progreso y de defensa de la nacionalidad, propagado sólo por una élite intelectual.

b) El concepto de nacionalismo ha tenido varias acepciones a lo largo de toda la historia dominicana por lo que ha sido asumido desde diferentes perspectivas, pero dentro de ellas sobresalen dos posiciones esenciales.

1. Un nacionalismo cerrado que ha pretendido concatenar la idea de patria, nación, identidad, cultura, idealizando la historia o parte de ella, y que propugna una idea de la nación a partir de símbolos, signos y emblemas propios de una república libre de toda dominación extranjera, en especial haitiana.

2. Un nacionalismo crítico y abierto vinculado a la visión de transformación de la sociedad, la historia y la cultura. Este es un nacionalismo dinámico que reconoce el carácter dialéctico de la cultura y de la historia dominicana, que reconoce la existencia de una cultura alternativa desde sus raíces más populares y que clama por los estudios específicos y críticos sobre ella.

A partir de los análisis críticos y objetivos de estas tendencias se definen (Odalis Pérez, 2003) dos maneras esenciales de ver la cultura y la identidad cultural. Una forma estática a manera de un monumento, que tiene bases esenciales en la hispanidad o el hispanismo, y que define la dominicanidad como un modelo identitario culminado, hecho, y por tanto paralizado o estático. Una forma dinámica o en movimiento, que concibe a la dominicanidad y a la cultura dominicana como algo dialéctico que ha tomado y toma cuerpo dentro de la diversidad Ambas formas de concebir la cultura entroncan a su vez con las lecturas nacionalistas antes expuestas, y por tanto se inclinan, o hacia la elitización de la cultura y personificación de la misma, o hacia la introducción en las raíces más profundas de lo colectivo, del cuerpo social, y por tanto en las raíces de la diversidad étnica. 
Las perspectivas teóricas caracterizadoras de esta tendencia han tomado cuerpo en las investigaciones más recientes sobre la migración haitiana. y dentro de ellas en el tratamiento de factores esenciales como: los orígenes y las causas de la migración: los factores que han determinado y determinan la estabilidad y el dinamismo de estos movimientos poblacionales a través del tiempo: las incidencias de la incorporación de los inmigrantes en determinados sectores dentro de la economía dominicana: además del estudio de los procesos de adaptación y las influencias culturales de los inmigrantes en esta sociedad.

Las aproximaciones a los elementos culturales como la religion. lengua, sistema de valores o modalidades particulares de comportamiento cotidiano, han sido la otra nota distintiva en sus estudios sobre la migración haitiana, a lo que se agrega el análisis de como estos aspectos se han asumido entre los mecanismos justificadores de los estereotipos y formalizadores de las diferencias y la discriminación étnica.

Es a partir de esos estudios esclarecedores es que se ha vislumbrado como la práctica racista y de segregación étnica contra los inmigrantes haitianos no sólo sirve para justificar una determinada ideologia, sino tanbién como mecanismo reproductor de desigualdades sociales. y como factor desfavorable en el proceso de integración o asimilación por la sociedad dominicana del conjunto de inmigrantes. En otras palabras ha puesto al desnudo el proceso de inserción excluyente de estos inmigrantes.

Las investigaciones con esa perspectiva han privilegiado tanto los enfoques cualitativos como los cuantitativos para incursionar en las vivencias de los individuos, sus percepciones de las relaciones sociales. su cultura, y el impacto en la cultura receptora. En ese sentido es importante senalar que los principales conceptos que se manejan establecen una dinámica diferente al tratamiento del tema, la misma se encuentra completamente alejada de los enfoques prejuiciados, anquilosados o estáticos sobre la identidad dominicana.

La óptica asumida en este caso privilegia un carácter dinámico de la identidad observándola en sus dimensiones de continuidad y cambio, y resaltando el aparente estado de contradicción entre ambas dimensiones. Así la identidad no se asume como una constante mecánica o una repetición idéntica de lo mismo, sino más bien como algo dialéctico por una integración del otro, por el cambio dentro de la continuidad. La identidad es por tanto concebida como un proceso de constante acondicionamiento de las diferencias, incluyendo a los contrarios. En otras palabras la identidad es 
una estructura donde la diversidad y las diferencias son constantemente integradas en un conjunto coherente ${ }^{19}$ (Silie, et al: pag. 43-44)

Otro concepto fundamental que se asume desde una perspectiva creativa dentro de esta tendencia es el de etnicidad ${ }^{20}$. En ese sentido el concepto percibe a la etnicidad como algo multidimensional, que contiene una dimensión objetiva, una dimensión subjetiva asociada con el sentimiento de pertenencia a un grupo, además de una dimensión relacional vinculada a la construcción social de la diferencia y asociada a las redes sociales. instituciones, organizaciones, intereses políticos. económicos que puedan movilizar a un grupo (Silie, et al : pag 51-53).

Esta dimensión múltiple en que se aprecia la etnicidad, evidentemente también ha remitido hacia una repercusión de la propia definición de identidad étnica, la que en este caso se ha observado no sólo desde su dimensión objetiva externa, sino también en una dimensión subjetiva interna que apunta hacia el sentimiento de pertenencia a un grupo fundamentado en una historia, una cultura y un provenir compartidos, más que hacia una identificación a partir de la visión excluyente o exclusivista de la propia identidad étnica que ha tenido como trasfondo la espada de Damocles del inminente peligro de la absorción cultural haitiana.

Es el abordaje de la dimensión cultural del fenómeno de la migración haitiana el que ha ido tomando fuerza en los últimos tiempos, y con ello se ha perseguido comprender la dinámica de la construcción identitaria de los

19 Rubén Silié, Carlos Segura y (arlos Dore, I.a Nucra inmigracion haitiana. FLACSO. República Dominicana, 2002 ?

20) La concepción subjetiva de la etnicidad la considera en relación directa con la identidad individual y con la conciencia de pertenencia a un grupo, por lo que el individuo es colocado en el entro de este concepto, es el quien expresa un sentimiento de pertenencia que puede conducirle a realizar actividades que expresan su propia etnicidad. De esta manera el grupo étnico es concehido como una suma de las conciencias étnicas. La visión ohjetivista de la etnicidad remite a los aspectos que pueden ser concretamente identificados, a un enfoyue empirista, y la ctnicidad generalmente concebida como algo immutable o fijo.

()tros enfoques sobre la etnicidad sostienen que esta surge por diterenciación. es decir que es en relación con el otro que surge la conciencia étnica. Es a partir del contacto con el otro que un grupo cultural toma conciencia de las diferencias que amenazan el sentimicnto de seguridad suministrado por la cohesión cultural.

Algunos autores también insisten en la dimensión comunitaria de la etnicidad, la que remite a una historia común, a redes sociales, o intereses económicos o politicos movilizadores de un grupo, y por otro lado a las dimensiones culturales que sirven de base a la identidad individual. y a la herencia histórico cultural común. 
inmigrantes, pero también del propio pueblo dominicano, a partir de concebir la misma como algo dinámico y no estático, como algo no terminado y concluido, sino como algo a lo que constantemente se integran nuevos elementos y que tiene la capacidad de reformularlos y hacerlos suyos. En resumen se ha tratado de privilegiar una visión de la identidad nacional y de la propia nación dominicana lejos del sentimiento excluyente, pesimista y fatalista que caracteriza a la tendencia del "Ocaso".

\section{Una visión comparativa a raíz de la nueva situación. Un estudio de caso}

Los trabajos de campo sobre los que se generó nuestra nueva perspectiva se realizaron en dos localidades con una concentración importante de inmigrantes haitianos o de sus descendientes. La primera de ellas es una comunidad conocida como batey de Palavé, ubicada en una zona sub urbana en las afueras de la ciudad de Santo Domingo, y la segunda es una zona con gran movimiento y trasiego comercial informal, realizado fundamentalmente por haitianos, que se localiza en el mismo corazón de la capital dominicana, detrás del llamado mercado modelo, y es conocida como el Pequeño Haití.

El trabajo de campo en ambas localidades se basó esencialmente en la observación cualitativa y en la aplicación de entrevistas a profundidad a una muestra más o menos significativa de nuevos inmigrantes haitianos (147 en total), para ello se recibió ayuda invaluable de estudiantes del INTEC, quienes participaron como entrevistadores y observadores a través de la asignatura de Antropología Social y Procesos Sociohistóricos Dominicanos ${ }^{21}$.

21 Durante estos trabajos de campo los estudiantes además de fungir como entrevistadores fueron orientados por grupos para observar determinados aspectos de la vida cotidiana así como de la cultura material y espiritual de los immigrantes. A partir de aquí se generó un registro fotográfico, materiales de video protocolos de observación cuyos resultados fueron expuestos y debatides por los estudiantes en clases. Los trabajos de campos se llevaron adelante n dos campañas. La primera de ellas durante el trimestre Diciembre-Enero del 2004 y la segunda durante el trimestre FebreroAbril del 20165. Durante la primera de estas campañas se contó con la valiosa participación de la profesora y antropóloga trátima Portorreal, quien se integro a esta parte de la investigación con sus estudiantes. 
Como base de las comparaciones e interpretaciones también empleamos los resultados y la perspectiva teórica asumida en la obra citada de Rubén Silié, Carlos Segura y Carlos Dore. La Nueva inmigración haitianc, la que constituye la más reciente caracterización de la migración haitiana hacia la República Dominica?2.

A los efectos de viabilizar la comprensión de los diferentes aspectos ahordados en la investigación de campo. la exposición de los mismos será desarrollada de manera particular y con una perspectiva comparativa evaluadorat.

\section{Datos generales de la población estudiada}

En el batey de Palavé se realizaron 89 entrevistas a profundidad en inmigrantes haitianos y una cantidad similar a descendientes, sin embargo a los efectos de la presente investigación sólo tomaremos en cuenta los datos arrojados por los inmigrantes en tanto este sector poblacional constituye el centro de nuestras observaciones.

En el caso del Mercado Modelo fueron entrevistados un total de 58 immigrantes haitianos y cerca de 10 dominicanos de ascendencia haitiana, pero al igual que para el caso anterior sólo hemos tomado las informaciones correspondientes a los inmigrantes.

En sentido general se pudo precisar una mayor incidencia de inmigrantes de sexo femenino en ambas localidades, característica que no era común en años anteriores ${ }^{23}$. Otro rasgo interesante es que en el caso de Palave la mayoría de los entrevistados son casados o se observa incidencia significativa de uniones maritales informales. lo cual parece coincidir con su condición de centro receptor de inmigrantes con mayor antigüedad, lo que a su vez se reflejaría en la existencia de un grupo migrante establecido, incluso con mayor descendencia local. Por su parte en el caso del Pequeño

22 Fsta obra recoge los resultados de dos investigaciones, la primera de ellas referida a las caracteristicas sociodemográlicas, la situación ocupacional y el universo cultural de los inmigrantes hatianes que realizan actividades en sectores urbanos, mientras la segunda recoge una caracteri/acion sociocionomica y cultural de los descendientes de haitianos nacidos en la República Dominicana.

23. Annque la mayor parte de los entrevistados fueron del sexo masculino, sin embargo la diferencia es minima lo cual parecer ser evidencia del aumento de la inmigración femenina. Fsto como ya se ha dicho refleja una situación de cambio respecto a momentos anteriores. Sobre todo la mayoria de las mujeres entrevistadas se dedican a la aetividad del comercio informal. 
Haití la incidencia de la población casada o con uniones maritales informales muestra un índice menor, lo cual coincide con los rasgos de una población donde los rangos etarios se comportan más equilibrados es decir el índice de jóvenes (entre 15 y 25 años y entre 26 y 35 años. es equivalente y casi en equidad con los mayores de 36 años). Esto señala hacia inmigrantes de más reciente ingreso al país y por tanto con menores posibilidades de haber generado descendencia lo cual repercute en mayores índices de soltería. Ambos rasgos a su vez coinciden con la mayor incidencia de la migración actual hacia las zonas urbanas y no hacia las zonas rurales como los bateyes, este el caso de Palavé.

Un rasgo común a la población migrante de ambas comunidades. en este caso los que expresaron poseer uniones maritales. es la preferencia por buscar pareja entre individuos de la misma etnia.

Los rangos de edad predominantes se encuentran entre los 15 y 25 años y entre los 26 y 35 años, seguido por los inmigrantes que se encuentran entre los 35 y 60 años de edad. El primero es común en la mayoría de los inmigrantes, no sólo haitianos, sino en sentido general, en tanto es la edad de mayores posibilidades y de madurez productiva de los individuos. Llama la atención que sólo siete de los entrevistados se desempeñan dentro de actividades agrícolas mientras la mayoría se desempeña en actividades informales de comercio o de albañilería, así como en funciones de trabajadoras domésticas. Otras actividades como choferes o artesanos están levemente representadas.

En algunos casos, sobre todo entre las mujeres, se observa la carencia de un empleo fijo, muchas veces suplidas por labores comerciales informales temporales, vinculadas a la venta de productos alimenticios de producción casera, u otros productos lo que le pueden proporcionar algún ingreso alternativo.

Algo interesante con respecto a la población migrante del batey de Palavé, anteriormente muy vinculada a la actividad agrícola, sobre todo la producción azucarera, es que en la actualidad la mayoría de ellos/as laboran en zonas urbanas de la capital en actividades de la construcción u otras labores informales. Esta característica es razonable si se toma en cuenta la perdida de importancia de la producción de azúcar y por tanto el alto índice desempleo existente en esta zona.

Por su parte en el Pequeño Haití se observa un panorama diferente, en ella se percibe una economía informal en la que existen pequeños puestos de venta de objetos turísticos, sin embargo esta no es la clase esencial de 
productos ofertados en el área, más que nada sobresale la venta de flores de diversas clases, frituras, jugos, casabe, frutas, legumbres, hortalizas y verduras. La mayoría de los consumidores de estos productos son dominicanos. Mayormente los propietarios de los puestos eran quienes trabajaban en ellos, no se observa una línea divisoria entre vendedores haitianos y dominicanos y existe una relación pacífica entre ellos. A este respecto resulta interesante la declaración de un inmigrante haitiano de este sector "los dominicanos son solo racistas de la boca para afuera". Sobre esta actividad económica informal desarrollada por los inmigrantes es necesario plantear que muchos de ellos tienen sus hogares en la misma y que la mayoría de ellos deben pagar un impuesto al ayuntamiento para poder colocar sus puestos de venta en las aceras y demás lugares de esa zona

El promedio de hijos resultado de las uniones maritales o informales entre los inmigrantes de estas localidades se encuentra entre 1 y 3 hijos, y mayormente se trata de hijos nacidos en la República Dominicana. En este caso resulta interesante la estrategia de negación o evasión de conflicto empleada en algunos casos donde se niega que ellos o sus hijos hayan nacido en Haití. Esa estrategia sin embargo se contradice con el reconocimiento por parte de la mayoría de ellos/as de una descendencia haitiana. Por ejemplo el $93.9 \%$ de los entrevistados en el Pequeño Haití reconoció su ascendencia haitiana. sin embargo en su mayoría negaron haber nacido en Haití, lo que evidentemente se relaciona con un resguardo respecto a su condición o estatus migratorio en República Dominicana. Esta situación también resulta interesante, porque como se observa si bien no se niega directamente la relación étnica y cultural con Haití a partir de la ascendecia, sin embargo si se observa una evasión o una negación en cuanto al lugar de procedencia, esto como se ha dicho parece estar más a tono con el estatus de irregularidad o de discriminación a la que se encuentran expuestos los inmigrantes. En otras palabras lo que se niega en si mismo es esta condición. En esos casos se asume que el estatus se relaciona más con su lugar de origen o nacimiento que con el reconocimiento de una relación cultural que rememore su relación con lo haitiano.

Los datos aportados sobre las condiciones de la migración de estas personas resultan muy interesantes, en el sentido de que en su mayoría emigraron solos, pero se observa una tendencia al incremento de las migraciones con la familia o parte de ella. De los 147 entrevistados en total unos 54 emigraron con sus familias o parte de ellas, otro factor interesante es el poco tiempo que tienen residiendo en el país, pues la mayor parte 
sólo tiene residiendo cerca de 5 años o menos en República Dominicana, mientras sólo unos pocos tiene más de 10 años ${ }^{2+}$.

Estos datos resultan importantes pues refuerzan varios de los aspectos esbozados anteriormente sobre las características de una nueva migración haitiana, en tanto su tendencia a establecerse en zonas urbanas o marginales de la ciudad, además de lo relacionado con las redes familiares y su trascendencia en el actual proceso migratorio. Se observa que la existencia de vínculos familiares, parentales o de amistad han conllevado a un incremento de las migraciones en grupos o que las personas aún cuando puedan emigrar solas, posteriormente y de acuerdo a las condiciones creadas en el lugar, se preocupen por una reunificación familiar. En el caso específico del batey de Palavé el $65.9 \%$ de nuestros entrevistados expuso haber emigrado con su familia o al menos parte de esta, mientras el $34.1 \%$ reconoció haber emigrado sólo. Por su parte en el Pequeño Haití la tendencia es contraria el $57.7 \%$ expresó haber emigrado solos y el $42.3 \%$ reconoció haber emigrado con su familia (es más representativo de la tendencia actual). En este mismo sentido podría pensarse que Palavé es una comunidad esencialmente de recepción y de tránsito de los nuevos inmigrantes, en tanto el poco tiempo de permanencia en ella de la mayoría de los entrevistados.

Un fenómeno interesante del proceso migratorio haitiano actual no sólo parecer ser la migración directamente desde Haití hacia zonas urbanas de Santo Domingo sino la propia migración interna de esta población una vez arribados a la República Dominicana. El 93,3\% de los entrevistados en la zona del Pequeño Haití admitió haber residido en otra provincia del país antes de haber arribado a Santo Domingo. Como ya se ha expresado esto se relaciona con las posibilidades temporales del mercado de trabajo.

Entre las causas fundamentales que impulsaron estas personas a emigrar se encuentran en primer lugar las posibilidades de oferta laboral en el territorio dominicano y por tanto las causas vinculadas a los aspectos económicos, además de la necesidad de ayudar a sus familiares o escapar de los problemas que actualmente enfrenta la nación haitiana.

24 Según los datos estadísticos aportados en la obra de Ruhen Silić. et al. La Nenera inmigracion /laitama (pág 91-92). la población migrante esta compuesta en su mayoria por personas jóvenes. La edad oscila entre 20 y 40 años y las mujeres entre 25 y 40 . La mayor parte de estas personas son solteros y de los que son casados y tiene hijos en su mayoria tiene uno solo lo que se corresponde con su juventud. Muchos de los hijos de estos inmigrantes $\left(38^{\circ}, 0\right)$ macieron en este pais mientras otros $(13.2 \%)$ tienen hijos nacidos en los dos países, lo cual indica un establecimiento en la República Dominicana. 


\section{Los rasgos culturales en la actual situación migratoria}

La conservación de los aspectos que definen la etnia de los haitianos que habitan en territorio dominicano es palpable a través de cierta unidad de conciencia entre ellos, o en aspectos de orden social, cultural. lingüístico. religioso e incluso místico. A pesar de su anhelo por preservar esa identidad la redefinición de la misma se hace imprescindible en una sociedad diferente en muchos aspectos. donde la ausencia de un entendimiento y una aceptación común sobre las costumbres y valores culturales haitianos estimulan una especie de rigidez o de barrera con respecto a estos. Ante esta situación los inmigrantes pueden asumir como estrategia aferrarse más a su cultura al estar inmersos en una sociedad poco receptora que ha sido intransigente en cuanto a establecer las condiciones que les permiten integrase como minoría, o asimilarse y aculturarse a esta misma sociedad como una estrategia de supervivencia dentro de ella.

El predominio de cualesquiera de estas estrategias se encuentra relacionado con una multitud de factores ${ }^{25}$, entre los que cuentan: la coyuntura económica al momento de la llegada, la política migratoria del país receptor, en este caso la República Dominicana, las capacidades del grupo, y las facilidades encontradas para constituirse o no como una comunidad. En ese sentido también influyen la propia posición del inmigrante en la cadena generacional y la clase social a la que pertenece.

\section{EI lenguaje}

La lengua es el elemento de mayor identidad entre los inmigrantes y de alguna forma es una de las expresiones característica de que estos constituyen un grupo homogéneo en términos sociales y culturales ${ }^{26}$. A pesar de ello el patrón tradicional de la migración haitiana ha reflejado que la mayoría de los inmigrantes hablan español, o han adoptado este idioma como parte de los valores dominicanos asimilados.

25 Rubén Silié, Carlos Segura, Carlos Dore Cabral. La merva inmigracion hatitana. FLAC SO, República Dominicana, 20102 .

26 Según la Enctuesta sohre inmigrantes haitianos en Repuhtica Dominicana, FLACSO-OHM. 2004 pag. 63. el idioma por excelencia utilizado por la mayoria para la comunicación entre sus familiares en sus casas es el creole $(87.8 \% 9$ y en menor medida el español $(10 \%)$. Mientras en la comunicación con sus compañeros de trabajo el idioma más utilizado es el español seguido del creole. 
La afirmación es congruente con los resultados de una encuesta realizada en 1998 por la Agencia para el Desarrollo Internacional (USAID) en diez ingenios azucareros del CEA, la cual reveló que cerca de un $52 \%$ de los encuestados admitió tener conocimiento del creole. mientras el $43 \%$ admitió que no sólo no lo habla sino que tampoco lo entiende ${ }^{27}$.

Aunque estos datos no dejan de ser interesantes y pueden ilustrar las influencias de la cultura dominicana en los inmigrantes, los mismos deben observarse con cuidado en tanto hay que tomar en cuenta que la negación del cróele, puede estar influida por la condición de discriminado de este segmento de la población así como el hecho de estar sometida a prejuicios tanto raciales como de nacionalidad. En muchos de estos casos la negación de la pertenencia a la nacionalidad haitiana puede asumirse a partir de la negación de conocer o hablar el creole, lo cual debe tomarse como un mecanismo de autoprotección y preservación, más que como un mecanismo de asimilación total a la cultura receptora. Este es un factor a tomar en cuenta.

En otras palabras ante una situación de marginación social y cultural el individuo o el grupo inmigrante ha asumido estrategias identitarias desarrolladas en función de aligerar las tensiones que les resultan de las limitaciones impuestas por el propio entorno social, es decir por la propia prescripción de su identidad o por los roles preconcebidos que se les han asignado a la misma. En ocasiones esos roles pueden ser asimilados y en otras ocasiones rechazados, lo que se encuentra en gran medida en correspondencia con los propios recursos de que disponen los individuos o el propio grupo.

El empleo del cróele para comunicarse entre sí y el uso en menor escala del español es una muestra de que su cohesión étnica les estimula a hablar la misma lengua cuando están radicados en un ambiente humano donde conviven con las mismas tradiciones, constituyéndose en un factor que reglamenta las relaciones en su vida cotidiana.

El caso específico de los resultados de nuestras entrevistas en Palavé resulta congruente con las afirmaciones anteriores, pues el 91.5.\% de los entrevistados reconoció saber hablar cróele, mientras sólo el $8.5 \%$ afirmo no saber hablarlo, algo similar se observa para el Pequeño Haití donde el

27 Resumen Ejecutivo, bateyes del Estado. Encuesta socioeconómica y de salud de la población materno- infantil. 
91.5 de los entrevistados admitió hablar cróele y sólo 8.5\% negó hablarlo. En cuanto a las preferencias por hablar un o u otro idioma la mayoría también coincide con sus preferencias por el cróele, mientras sólo un porciento ínfimo admitió preferir utilizar ambos idiomas $(11.1 \%$ Pequeño Haití y $16.4 \%$ en Palavé). Estos datos resultan a su vez ilustrativos de lo que planteabamos sobre las estrategias de adaptación a su situación social, pues la mayoría de los entrevistados manifestaron su preferencia por el creole aduciendo considerarla su lengua madre pero además en su totalidad precisaron que les resulta difícil hablar español y justificaron la necesidad de hablarlo en tanto las posibilidades de comunicarse en el medio donde viven y los requerimientos de sus relaciones sociales y económicas.

En el caso del Pequeño Haití el número mayor de los entrevistados expresó sus preferencias por el creole argumentando como razón de peso el hecho de tratarse de su lengua materna, y por tanto el hecho de hablarlo con otras personas les inspira mayor seguridad y confianza. En el caso de los que expresaron sus preferencias por hablar español. algunas de las razones de esta preferencia, que fueron las menos, merecen atención en tanto la siguiente respuesta: "porque no hablo con los que hablan creole". es una muestra de rechazo o renegación de su propia etnia al asumir una forma de asimilación a la cultura dominicana

Esa estrategia de negación es una de las posiciones que puede asumir el inmigrante haitiano ante la situación que se genera en la sociedad y la cultura dominicana receptora, su aplicación implica el alejamiento a toda costa del grupo de origen e incluso el hecho de expresarse con cierto desprecio hacia este. Una expresión precisamente de esta estrategia es el hecho de no admitir expresarse en cróele, negar su condición de haitianos. definirse como dominicanos o en otros casos no conceder importancia a la filiación étnica. La mayor parte de los que aplican ésta estrategia generalmente presentan ingresos promedios superiores a la mayoría del resto de los inmigrantes.

En este mismo sentido el aspecto de la negación del idioma o de otros aspectos de la cultura, como la religiosidad no sólo es propio de los inmigrantes haitianos hacia República Dominicana, sino que en este sentido algunos intelectuales haitianos (Jean Ghasmann, 20()2, pag 27) ${ }^{2 \mathrm{x}}$ han afirma-

28 Jean Ghasmann. Paradigma de la Migracion Haitiana en Repithlica Dominicana. Instituto Tecnológico de Santo Domingo, República Dominicana. 20022. 
do que la lengua, el color, y la religión, han sido manipuladas por la propia política haitiana. Según este autor ni el vodú ni el cróele son elementos determinantes dentro de la cultura haitiana, en sus opiniones el vodú y su fuerza cultural no llega a suplantar la religión católica o bloquear la expansión vertiginosa de las iglesias protestantes. Haití por tanto siempre ha sido un país con grandes influencias francesas y se ha considerado un país católico o cristiano, por lo que honrar los valores católicos, según este autor, es afirmar su pertenencia a la cultura occidental. En síntesis la supremacía del Vodú sobre el catolicismo o el cristianismo, y del cróele sobre un idioma universal como el francés. no harían más que aislar a Haití del resto del mundo.

\section{La Religiosidad y los aspectos lúdicos}

Dentro de los rasgos esenciales que rememoran el universo cultural de origen de los inmigrantes haitianos en la República cabe destacar su religión, al punto que la región sur del país es considerada una zona particular dentro de la religiosidad popular debido a la gran influencia de los nacionales haitianos. Las influencias de la religiosidad popular haitiana en esta zona es evidente debido al intercambio fluido de la mayor parte de los emigrantes con la población que convive con ellos.

Según los estudios realizados por el ingeniero Elpidio Ortega ${ }^{29}$ en esta zona sur el $95 \%$ de los trabajadores tenía sangre haitiana en segunda generación o eran de nacionalidad haitiana, lo cual era fácil de detectar por su acento, facciones y sus nombres, y para esa época (1999) aún no se habían dominicanizado usando nombres con raíces españolas. Casi todos practicaban el Vodú o creían en lo sobrenatural, y una buena parte de ellos participaba en las actividades relacionadas con la magia, brujería y hechicería. Las incidencias del vodú eran tan importantes en esta zona que se consideraba una religión subyugante, y sus influencias eran muy notables tanto en expresiones de cantos religiosos así como en manifestaciones plásticas (Ortega, 2000).

El gaga es otra de las expresiones de religiosidad que los inmigrantes habían popularizado en los bateyes, el mismo se desarrolla sobre todo en

29 Elpidio Orega. Expresiones culturales del Sur. Publicaciones de la Academia de Ciencias de la República Dominicana. Santo Domingo, Repuiblica Dominicana, 2000). 
la cuaresma con un peregrinaje el viernes santo trasladándose a bateyes cercanos bailando y tocando, acompañados con bastones, un vestuario especial para la ocasión y algunos instrumentos confeccionados a base de bambú.

Un aspecto importante en la práctica del gagá que ha sido señalado por los principales estudiosos del tema (June Rosember,1979) es su inigualable erotismo con respecto a cualquier otra práctica religiosa conocida en el medio dominicano. El gaga es uno de los cultos más eróticos de la religiosidad popular dominicana y su contenido de este tipo no sólo se expresa a través de la sensualidad propia de sus danzas sino también, a decir de Carlos Andujar ${ }^{30}$. en sus cánticos, en los cuales muchas veces se utiliza un lenguaje obsceno para referirse a lo sagrado o abordar temáticas separadas totalmente de este.

En los estudios más recientes relacionados con la nueva inmigración haitiana (Silie. et al, 2002) se señala la influencia significativa del protestantismo como práctica religiosa entre muchos de los nuevos inmigrantes, cuya aceptación muchas veces se ha producido en el territorio haitiano o puede producirse en el territorio dominicano. En este mismo sentido también se ha señalado (Silie, et al. 2002) que en el aspecto religioso y mágico los haitianos y dominicanos de ascendencia haitiana tienen un comportamiento diferente, mientras se acepta como un hecho que la mayor parte de la población haitiana practica el vodú, la mayoría de la población dominicana de ascendencia haitiana plantea que no es practicante de vodú. Esta situación intenta explicarse por las diferencias de contextos religiosos en que se mueven estas personas.

$\mathrm{Al}$ decir de Silie et al, el vodú como cosmogonía explicativa de la vida y la muerte en Haití es una expresión religiosa reconocida constitucionalmente, y en consecuencia no está sometida, al menos legalmente, al hostigamiento por parte del estado u otros sistemas religiosos formales. En el caso de la República Dominicana este tipo de ritual es una especie de integración de las tradiciones africanas con los elementos del catolicismo, produciéndose un sincretismo que no constituye la cosmogonía esencial para la explicación de la vida y la muerte. Por otro lado estas prácticas no tienen ningún reconocimiento legal, y por el contrario se le considera una

30 "Sexualidad y religiosidad popular en los bateyes de República Dominicana" en Ecos. Órgano del Instituto de Historia de la Universidad Autónoma de Santo Domingo. Año IV No. 5 1996, p. 201 
especie de brujería hostigada por el estado y por las religiones formales. Esto último coincide con que la mayoría de la población de inmigrantes haitianos o de población dominicana de ascendencia haitiana plantea ser cristiana, sobre todo católica ${ }^{31}$.

La evidencia directa de este último planteamiento también fue arrojada por nuestro trabajo de campo. Al analizar los resultados de las 147 entrevistas realizadas en los dos contextos señalados anteriormente 41 de los entrevistados se reconocieron como católicos, mientras 76 se reconocieron como evangélicos, metodistas, adventistas, testigos de Jehová. Unas 29 personas se reconocieron como practicante de otras religiones o simplemente creyentes en Dios, mientras una sola persona de las entrevistadas reconoció directamente practicar vodú.

Otros datos a su vez coinciden con la negación de la práctica de este tipo de expresión religiosa, 86 de los entrevistados afirmaron haber estado siempre dentro de una misma creencia, mientras sólo 17 reconocieron haber cambiado hacia las mismas, y el resto prefirió no responder esta pregunta.

Algo interesante al respecto fue constatado en la comunidad de Palavé, donde existe una gran proliferación de iglesias evangélicas y una sola iglesia católica. Las entrevistas realizadas a varios de asistentes a estas iglesias revelaron la asistencia de una mayor cantidad de haitianos a estas, además de referenciar la existencia de planes, cursos de verano, actividades y campañas encaminadas a desarticular las prácticas de vodú, gaga y otras expresiones religiosas populares dentro de la población del batey. Por su parte las entrevistas realizadas entre los asistentes a la iglesia católica reveló una menos afluencia de población haitiana o sus descendientes a esta además de no reconocerse la existencia de algún proyecto o labor proselitista por parte de esta para atraer a esta población

El análisis de los datos sobre actividades lúdicas es sintomático y evidencia una estrecha relación, además de cierta contradicción, con los datos sobre religiosidad anteriormente analizados. Una buena parte de los inmigrantes entrevistados ( 114 en total) negaron su asistencia a cualquier fiesta

31 Según la Encuesta sobre inmigrantes haitianos en Republica Dominicana el 53, $9 \%$ expresó practicar la religión católica y el $25,3 \%$ planteo ser protestante. sólo un 3\% reconoció practicar el vodú. Estos datos coinciden con la afirmación del $52,1 \%$ de no participar en fiestas o actividades vinculadas a la religiosidad. pag. 63 
de carácter religioso (Gagá, Congo, Vodú), y sólo 33 admitieron asistir a este tipo de prácticas. En contradicción con esto y con la religión que dicen profesar, al preguntarles sobre las similitudes entre este tipo de ceremonias religiosas en República Dominicana y Haití, muchos respondieron que no observaban diferencias en este sentido, lo cual evidencia un conocimiento previo o actual de los rituales o expresiones lúdicas vinculadas a este tipo de creencias. La contradicción en ese caso vuelve a florecer pues la mayoría consideran malo o diabólico este tipo de celebraciones.

Algo muy interesante a este respecto es que las observaciones realizadas con respecto a las viviendas de los inmigrantes en Palavé arrojó que en el $20 \%$ de ellas se observaron objetos de carácter religioso relacionados con practicas de Vudú o se constató la existencia de altares. En el $80 \%$ se observaron otros objetos como santos, ángeles, etc.

Las actividades lúdicas que dicen celebrar están esencialmente vinculadas a fechas especiales de tipo religioso cristiano o católico, entre ellas la semana santa. la navidad, las patronales de diferentes santos u actividades más de orden social vinculadas al vecindario o instituciones como la escuela, o el carnaval, etc.

La música que se escucha en estas celebraciones es música haitiana y dominicana y generalmente puede ser música tocada o grabada. En el caso de la primera se encuentra en relación directa con las expresiones de religiosidad de que se trate. incluido el vodú, mientras en el caso de la segunda se refiere sobre todo el enteo de la bachata y el merengue, lo que coincide con las expresiones de cierta inclinación por esta música dominicana expresada por los entrevistados. En ese dato también debe tomarse en cuenta que las celebraciones de este tipo no sólo participan los haitianos. sino que se mezclan dominicanos y haitianos

En cuanto a la necesidad de un vestuario especial para participar en las celebraciones en las que dicen tomar parte más o menos regularmente, un número de entrevistados refirió la necesidad de vestuario especial mientras igual cantidad expresó que no era necesario un atuendo específico y un número levemente mayor de personas prefirió no contestar a esta pregunta lo que resulta muy sintomático en cuanto a la veracidad total de las respuestas emitidas. en tanto la afirmación de la necesidad de atuendos especiales para participar en determinado tipo de ceremonias podría poner al descubierto sus inclinaciones hacia determinadas formas de religiosidad censuradas por la iglesia y la sociedad dominicana y en la que afirman no tener participación. Sólo en el caso donde se reconoció la práctica de vodú 
se admitió la necesidad de un atuendo compuesto por un vestido blanco y pañuelos de varios colores, el resto de los que reconocieron la necesidad de un vestuario especial se refirieron a ropa formal o ropa de cierta calidad.

No obstante estas afirmaciones se hace necesario señalar que las observaciones de campo permitieron definir ciertos aspectos que como tendencia se expresan entre la mayor parte de los inmigrantes. Los hombres se distinguen muchas veces por el uso de camisas con colores muy llamativos o exagerados, además de figuras de rayas, cuadros, flores y otros, mientras entre las mujeres son comunes los peinados como trenzas. moños y cabellos postizos, constituyendo las tranzas el tipo de peinado más común.

Ambos casos, tanto las informaciones sobre actividades lúdicas como sobre la religiosidad, a nuestro juicio, nos delatan en su mayor parte una estrategia. una posición ante la sociedad receptora y de hecho frente a su cultura. La estrategia es de ajuste de acondicionamiento en función de situaciones, y esta gravita o influye sobre su propia autodefinición.

En el caso específico de nuestras entrevistas por lo que pudimos observar, dicha estrategia no se refugia en la cultura de origen y privilegia una definición de sí mismo que pone en primer plano la condición de haitiano. sino que se fundamenta en un intento de evadir los roles que le asigna la sociedad y la cultura receptora, el individuo no los asume, no los interioriza y se oculta la práctica de religiones tan connotadas para la mayor parte de los haitianos. como el vodú, o de expresiones lúdicas con un sentido también religioso como el gaga. La tendencia es más bien a expresar su aislamiento de este tipo de prácticas y auto reconocerse, o al menos hacer creer, cierta identificación con la religión dominante en el país, en especial la religión católica o en buena medida con las religiones protestantes. En síntesis su aptitud en este sentido trasluce los intentos de evadir cualquier tipo de confrontación con la cultura y religiosidad dominicana.

Pese a esta estrategia, que puede simular, o expresar cierta asimilación real a la sociedad y cultura religiosa dominicana, los inmigrantes gencralmente chocan con los prejuicios y los estereotipos imperantes en la sociedad en cuanto a las creencias profesadas por los nacionales haitianos. en especial los prejuicios en contra del vodú

\section{La Vivienda}

En cuanto a la vivienda de los inmigrantes es importante señalar que la mayor parte de los estudios sobre el tema migratorio han referido la 
vivienda de los inmigrantes vinculadas a los barracones, muy comunes en los bateyes y en las zonas rurales relacionadas con la inmigración de los antiguos braceros hacia las faenas agrícolas o las zafras azucareras.

En este caso también sobresalen algunos estudios sobre las casas de tejamaní muy comunes en la región sur del país. en la que como ya se ha señalado existe una fuerte influencia haitiana en las expresiones religiosas y en otros aspectos culturales. En especial sobre este tipo de viviendas haitianas, vinculadas con una migración rural, se han estudiado sus métodos constructivos y sobre todo las expresiones plásticas o dibujos realizados en las paredes de muchas de ellas, los que hablan de una relación étnica con Haití entre sus habitantes o por lo menos de sus influencias en este tipo huella (Ortega, 2000).

La mayor parte de este tipo de viviendas que rememoran motivos religiosos a través de expresiones plásticas se localizan, según las investigaciones del ingeniero Elpidio Ortega (2000), a ambos lados de la carretera desde el pueblo de Baní hasta la frontera y su tendencia es a aumentar en la misma medida que el visitante se aproxima a esta última zona. La mayoría de las casas están decoradas con dibujos de color rojo, anaranjado o azules, y se trata de dibujos espontáneos realizados por sus habitantes.

El registro de estas expresiones plásticas realizado por Ortega (2000) incluyó 36 poblamientos de la zona sur en los que describe un estilo pictórico único, no sólo por su colorido y espontaneidad sino también por el mensaje que trasmiten. En sus descripciones es interesante la relación observada entre las prácticas religiosas de los habitantes y las representaciones pictóricas, en especial las prácticas de vodú y las representaciones de veves correspondientes a estos ceremoniales.

Los principales motivos relacionados con este particular incluyen representaciones fitomorfas, sobre todo palmas estilizadas con mucho parecido al diagrama del ritual rada del vodú, en especial las palmas de Dan Bhalah, Hwedo, Dan Bhalah la Fambó, Gran Bois. Los diseños fitomorfos también incluyen (Ortega, 2000) plantas florecidas y corazones que se confunden con manzanas, porque aparecen en la parte superior de los dibujos en una especie de tallo o ramas.Los corazones generalmente se representan con un punteado en rojo, lo que remite a fines religiosos ya que dibujos similares también se encuentran en el diagrama de Erzulie Freda y Diable Liglessou del ritual vodú

Otras figuras y diseños captados en el estudio de Ortega (2000) que señalan una relación con la religiosidad haitiana, en especial del vodú, son 
las figuras masculinas estilizada, similares a las que se representan en el ritual del barón del cementerio y en el veves de Grand Bois, además de representaciones de aves, como los pollos usados en los rituales y en los diagramas de Loco Ati sou

Entre los mensajes religiosos además de los motivos del veve aparecen frases entre las que se encuentra, Padre, Hijo y Espíritu Santo y dibujos de cruces $^{32}$. Las principales conclusiones de Ortega en este estudio llaman la atención al señalar la poca frecuencia de estas expresiones en Baní, lo que el autor explica por su lejanía de los núcleos esenciales de población haitiana, principales impulsores o influyentes en este tipo de manifestación, así como por la existencia de un núcleo fuerte de emigrantes canarios con un fuerte arraigo católico, por lo que su población es más reacia a las creencias o expresiones religiosas que dan origen a las manifestaciones pictóricas en las viviendas.

En resumen puede asegurarse que las pictografías en las paredes de los bohios del sur guardan una relación estrecha con la migración haitiana hacia esta zona, y es una característica específica que distingue a la viviendas en esas zonas rurales. Por otro lado estas se relacionan consciente o inconscientemente con la religiosidad popular, en especial con los rituales del vodú y mensajes religiosos católicos que representan el amor hacia la mujer y hacia la naturaleza, además de frases y cruces católicas asociadas a un sincretismo que toma forma en esas expresiones de arte popular.

En el caso de las viviendas haitianas del batey de Palavé cabe mencionar que su distribución esta confinada a un sector específico dentro del mismo. En sentido general se trata de viviendas con una alto grado de hacinamiento y en su mayoría conformadas por una sola piezas, se han construido de blocks, madera, $(50 \%)$ o zinc $(20 \%)$, sobre todo de estos dos últimos materiales. Carecen de algunos servicios básicos como agua potable o instalaciones sanitarias, estas últimas cuando existen son de usos común y se encuentran fuera de las viviendas. El promedio de residentes en cada una de las viviendas es 4 a 8 personas $(70 \%)$. Y cabe señalar que

32 En uno de los bohíos con dibujo Ortega encontró un hacha petaloide indigena sumergida en un tanque de agua, la cual según sus habitantes era una protección de la vivienda contra los ravos. un resguardo a la vivienda en tiempos de tormenta de las descargas eléctricas, aqui también se infiere una relación con el Vodú pues el hacha petaloide es un simbolo de la divinidad Dambhalah Wedo en el ritual rada del vodú. 
la mayoría de estas fueron construidas por los propios inmigrantes, y en otros casos donde se trata de alquileres deben pagarse una renta mensual de cerca de 200 pesos.

La situación de los inmigrantes, en especial hacia las zonas urbanas marca importantes diferencias en el aspecto de la vivienda que típicamente se ha descrito para los inmigrantes haitianos en las zonas rurales o con respecto al barracón que fue la nota distintiva en cuanto a vivienda en el caso de los braceros azucareros.

La mayoría de los inmigrantes entrevistados viven con su familia o parte de ella y en menor escala con amigos, compañeros de trabajo o solos. Se trata de viviendas alquiladas y no construidas por ellos. En este caso se puede inferir que los haitianos que se dedican a la actividad comercial, como la mayoría de nuestros entrevistados, disfrutan de mejores condiciones y mayores posibilidades económicas que el resto de los inmigrantes urbanos o rurales dedicados a otras actividades. El hecho de que la mayoría expresara vivir con su familia o parte de ella en casa alquiladas nos indica estas posibilidades, pues la mayoría de los inmigrantes vinculados a otros sectores, como el de la construcción, vive en casas de una sola pieza solos o con otros haitianos en los lugares de trabajo. lo que indica una separación de la familia. El otro elemento que refuerza las mejores condiciones del sector comerciante es el hecho de que la mayor parte de las viviendas fueron descritas como construidas de concreto. de zinc, madera y blocks, o de zinc y concreto.

La mayoría de los inmigrantes urbanos viven en barrios cerca de otros compatriotas, lo que denota la tendencia general a concentrarse en espacios donde pueden compartir con sus allegados. En otros casos, sobre todo en el sector de la construcción, muchos inmigrantes viven en el mismo lugar donde trabajan en lugares improvisados por ellos o por los propietarios. Io que económicamente le permite economizar el pago de las rentas pero a su vez permite una mayor explotación por parte de los propietarios. En esos lugares generalmente se refuerzan más los mecanismos de solidaridad entre los inmigrantes que en otros espacios donde la convivencia es más aislada.

El impacto en este caso puede ser una inclinación mayor hacia la persistencia étnica, sobre todo en el aspecto de la lengua, costumbres y hasta de credo o expresiones de religiosidad, sin embargo el hecho de que este espacio de práctica cultural pueda remitirse sólo a este marco estrecho de 
familiares o amistades, es decir a las relaciones primarias, atenta contra esa persistencia.

Al decir de algunos investigadores (Silie, et al. 2002) la gran dispersión del grupo haitiano, sobre todo estas nuevas oleadas migratorias, que se han insertado directamente en las actividades urbanas, es algo que conspira contra su persistencia étnica en el espacio dominicano, sin embargo los mismos autores afirman que puede tratarse de una etapa transitoria y precedente al desarrollo de una organización comunitaria.

\section{Aspectos culinarios y de alimentación}

Aparte de la lengua raras veces los inmigrantes establecen diferencias culturales significativas entre haitianos y dominicanos, por lo general se perciben como muy próximos a estos en términos culturales. aunque se siguen identificando con su país y su cultura de origen, independientemente del tiempo de residencia en la República Dominicana. En este caso un aspecto donde se aprecia una fidelidad y apego a sus orígenes pero también la interiorización de las asignaciones de la sociedad receptora es en el aspecto culinario y de alimentación.

Las entrevistas realizadas arrojan interesantes resultados en este sentido, que por demás confirman las conclusiones obtenidas en otras investigaciones (Rosario, 1989), pero a su vez indican una mayor amplitud en el sentido de una importante simbiosis de platos dominicanos y haitianos en el tipo de alimentación preferida por estos nuevos inmigrantes.

La mayoría de nuestros informantes expone no haber cambiado sus comidas preferidas y en el caso de los que afirman haber transformado sus preferencias en este sentido argumentan como razón de peso el hecho de haberse acostumbrado al país.

La mayoría también admite consumir con frecuencia platos de origen haitiano como el chenchen y el millo además de platos típicos dominicanos como el conocido por La Bandera (arroz, frijoles y carne). En el tipo de productos consumidos no se encuentra la mayor diferencia en este caso. pues como ya se expuso al inicio el hecho de compartir un mismo espacio geogrático provoca que la variedad de productos existentes en ambas partes de la isla sea la misma, e incluso la variedad de platos exhiba importantes similitudes. En ese caso los inmigrantes manifiestan sus preferencias por el sancocho, arroz con maíz o con chivo, pollo, harina de maíz. pescado, y plátanos. En otros casos también se percibe una preferencia por 
consumir productos que permiten un mayor rendimiento y en aminorar los costos en este renglón. Se trata de productos como los spaguettis y el salami, también con alto consumo entre las clases más pobres dominicanas

Las diferencias esenciales reconocidas por los inmigrantes tampoco se encuentran en los medios empleados para confeccionar los alimentos, que son esencialmente los mismos empleados en República Dominicana y están en relación con el poder adquisitivo y el estatus económico de las personas ${ }^{3.3}$. Las principales diferencias reconocidas se encuentran en el aspecto de la confección de los alimentos así como en el sazón. En estos casos la mayor parte de los entrevistados coincide en una mayor condimentación de las comidas por parte de ellos, sobre todo el uso de picantes y otros productos naturales que refieren no emplearse o no existir en la República Dominicana, como el poo y el pici. En el caso de los condimentos también es muy frecuente el empleo de sazones de fabricación industrial, como las llamadas sopitas, a los que los inmigrantes atribuyen diferencias con las utilizadas en Haití. A pesar de estos aspectos es justo señalar en su mayoría no se reconocieron grandes diferencias en este sentido

En resumen podría plantearse que aunque la mayoría de nuestros entrevistados manifiesta una preferencia por las comidas y bebidas típicas haitianas, no expresaron rechazo hacia la comida dominicana, y la mayoría de las diferencias admitidas se refieren más a la forma de preparación (sazón)de los platos que a grandes diferencias en las formas de alimentación.

Es en el aspecto de las bebidas es donde quizás se exhiben la mayor dicotomía entre las preferencias de los inmigrantes y los patrones de la cultura receptora. Aunque en su mayoría reconocen consumir o adaptarse al consumo de las bebidas dominicanas se observa una mayor variedad e incidencia en las bebidas típicas haitianas, entre las más mencionadas se cuentan el Gomallé, Juna, Banbancort, crema de coco con alcohol, jugo de caña fermentado, mabí de piña y Cleren.

En cuanto a las diferencias en la preparación de bebidas haitianas fermentadas o que contienen alcohol en la República Dominicana, la mayoría coincidió en que, para la preparación de este tipo de bebidas el alcohol no es el mismo por lo que el producto terminado adquiere un boqueé diferente.

33 Las informaciones proporcionadas por los inmigrantes y nuestras observaciones de campo indican que los principales medios empleados para elaborar los alimentos son estufas de gas, fogones de leña y anafés de carbón, con predominio de estos últimos. 


\section{Salud y medicina tradicional}

Las enfermedades más comunes dentro de los inmigrantes están relacionadas con sus precarias condiciones de vida y el estado de hacinamiento y segregación a que están sometidos en la mayoría de los casos, y por tanto con las condiciones higiénicas de los lugares de habitación, en los que generalmente están ausentes servicios básicos como el agua u otros servicios relacionados con la higiene sanitaria. Entre las enfermedades más comunes en este caso sobresalen las afecciones estomacales como vómitos, diarreas, amebas, además de piojos y fiebre tifoidea. etc.

Otras afecciones comunes y propias de países tropicales como, la gripe y las dolencias de la garganta también están presentes entre los inmigrantes y no se descarta la presencia de enfermedades con un ciclo de incubación mayor y de extrema gravedad como el SIDA. Esta última producto de una falta de educación sexual que no sólo es propia de los inmigrantes sino de una parte considerable de la población dominicana.

En contraposición a esto las respuestas de la mayoría de los informantes expuso una frecuencia baja en la ocurrencia de enfermedades entre ellos. Detectándose el mayor índice de respuestas positivas en este aspecto entre los entrevistados en el batey de Palavé, lo que parece coincidir con el mayor grado de hacinamiento y de condiciones higiénicas precarias en este sector que entre los inmigrantes entrevistados en la zona urbana del Pequeño Haití.

La forma de combatir las dolencias más comunes entre los inmigrantes remite al empleo de los servicios de salud (en el caso de Palavé existe un centro asistencial conocido como El Colibrí al que tienen acceso los pobladores del batey) pero en igual o mayor medida hacia el uso de medios alternativos que van desde la automedicación hasta el empleo de remedios caseros. La mayoría de los entrevistados coincidió en el uso de ambas alternativas (automedicación y remedios caseros) además de la asistencia a los puntos de salud ${ }^{34}$.

Entre los remedios caseros más frecuentes señalados por los entrevistados se mencionaron las infusiones o cocimientos de distintas hojas como

34 La encuesta de inmigrantes haitianos en República Dominicana. FLACSO-OIM. 2004. pag. 56. refiere que en caso de enfermedad el $79.5 \%$ recurre a comprar medicamentos en la farmacia. mientras el $11,2 \%$ toma brebajes y el $4,8 \%$ visita a una persona que sabe. 
el orégano, el limoncillo, limón, naranja, albahaca, cereza, guayaba, guanábana, canela, limón, entre otras, cuya forma de prepararlos dicen haber conocido antes de su arribo a la República Dominicana y en la mayoría de los casos afirman que esta no difieren en gran medida de las formas de preparación tradicionalmente conocidas por la población dominicana.

\section{Tres aspectos esenciales en los inmigrantes}

El abordaje de tres aspectos esenciales cerró nuestras observaciones y entrevistas en los inmigrantes haitianos de las poblaciones ya mencionadas, el primero de ellos se encuentra relacionado con la percepción que poseen estos de su inserción en la sociedad receptora, el segundo. con las relaciones y similitudes de la cultura dominicana con su propia cultura, y por último, las posibilidades de regresar a Haití ante un cambio o mejoría en la situación de ese país.

El primero de estos aspectos arrojó resultados interesantes y hasta cierto punto contradictorios. Entre las principales dificultades para su inserción en la sociedad receptora fueron referidos elementos de orden laboral, como encontrar empleo, o la intensidad y lo duro de las labores a realizar. aspectos de orden jurídico como las deportaciones y las redadas de la policía con este fin, aspectos de orden cultural, como aprender el idioma español, elementos de orden sentimental como la separación de la familia, o problemas de alimentación y salud.

En este caso los aspectos de mayor trascendencia fueron los de orden familiar y laboral además de los relacionados con el idioma. En el caso del primero y el último es evidencia del importante peso que tiene la unidad familiar ${ }^{35}$ dentro de la cultura haitiana así como el cróele, elemento de unidad cultural y étnica dentro del grupo. En el aspecto laboral las principales dificultades fueron achacadas más que a la intensidad de las labores a la posibilidad de conseguir empleo, lo que a su vez nos indica la incidencia de este factor como motivo esencial dentro de los generadores de la migración

En contradicción con estos factores mencionados en el caso de las entrevistas realizadas en el Pequeño Haití una buena parte de los entrevista-

35 En las entrevistas tanto a los inmigrantes que viven solos como aquellos que se encuentran acompañados de sus familias hablen de la importancia que esta tiene para ellos y para sus vidas, lo que denota un rasgo de fidelidad cultural a la cultura original en la que se proclama la preponderancia de la familia sobre el individuo. 
dos expresaron no haber tenido grandes dificultades para su inserción lo que juicio nuestro se traduce en un mejor posicionamiento de estos inmigrantes frente a la cultura del país de origen y a su vez de la sociedad que los recibe. en este caso la sociedad dominicana, de manera que se asumen estrategias a fin de aligerar tensiones y confrontaciones.

Si tomamos en cuenta que las relaciones entre dominicanos y haitianos evidentemente inciden en la formación de las imágenes que tienen unos de los otros, pero también de sí mismos, debemos a su vez considerar que dicha imagen se encuentra condicionada por el lugar que ocupa cada uno dentro de la sociedad, es decir por la relación de dominante y dominado que se establece entre ellos. Así las asignaciones que le otorga la sociedad dominicana a los inmigrantes haitianos son a su vez un aspecto central en la construcción o decontrucción de su identidad. El rechazo, el fomento de prejuicios raciales y el hecho de que los haitianos se inserten en actividades laborales generalmente rechazadas por los dominicanos, no sólo refuerza sus dificultades para insertarse dentro de la sociedad dominicana, sino que a su vez puede actuar como una especie de retroalimentación en el mantenimiento de su identidad étnica o como mecanismo para desarroIlan estrategias de inserción individuales o colectivas que les permitan un reacomodo a la sociedad dominicana y a sus condiciones.

Por su parte en el aspecto relacionado con las similitudes de la cultura dominicana con su propia cultura, la percepción de los inmigrantes entrevistados estableció diferencias. En general de los resultados obtenidos pudiera inferirse que aunque ellos/as consideran ambas culturas muy próximas, también se percibe que la mayoría continúan identificados con su cultura de origen

Los elementos en los que se perciben las mayores similitudes están relacionados con las comidas, las personas, las viviendas, las fiestas, y sobre todo en el aspecto religioso, lo que no deja de ser llamativo si tomamos en cuenta que este es uno de los aspectos en los que se ha generado mayores prejuicios con respecto a los inmigrantes, por lo que no es de extrañar que se reconozcan ante una agente externo como dentro de los cánones instituidos por la religiosidad local, lo cual a juicio nuestro puede inscribirse dentro de los mecanismos y estrategias de inserción ya mencionados.

En ese caso se trataría de un ajuste de un acondicionamiento en función de una situación concreta y por tanto en una estrategia que gravita o influye sobre su propia autodefinición en este aspecto religioso Aquí no se privilegia una definición de sí mismo que pone en primer plano la 
condición de haitiano, sino que se fundamenta en asumir uno de los roles, el religioso, que le asigna la sociedad receptora y puede en este caso específico estar ocultando la práctica de religiones como el vodú u otra forma de religiosidad no instituida en la República Dominicana

Una estrategia de evasión y a su vez de reafirmación étnica también se percibe ante el cuestionamiento de que ¿Si tuviera la oportunidad de asumir la ciudadanía dominicana lo haría? Una buena parte de los entrevistados respondió afirmativamente ( 33 en el mercado modelo y 51 en el caso de Palavé) pero la razón principal de esta afirmación se encuentra relacionada con la adquisición de una condición legal que les garantizaría una mejor inserción en la sociedad dominicana así como un reconocimiento de sus descendientes como ciudadanos dominicanos. En este mismo sentido se refieren las ventajas que esto acarrearía a su situación en tanto mayores posibilidades para conseguir empleo o llevar una vida más tranquila ante las amenazas de la deportación. La reafirmación étnica en este caso se percibe en las razones argumentadas por las respuestas negativas a este mismo cuestionamiento, y en las respuestas a la pregunta de un posible regreso ante una cambio de la situación haitiana.

En el primer caso en las respuestas negativas a hacerse ciudadanos dominicanos hay una referencia directa a su condición de haitianos, a la necesidad de mantener su cultura y tradiciones, o símbolos como la bandera, mientras en el segundo caso aunque es evidente una desesperanza o desconfianza con respecto a cualquier cambio de la situación económica y social haitiana, lo que motiva la mayoría de las negativas a regresar, a su vez se percibe una identificación muy estrecha con su país y su cultura, en tanto la mayoría de las respuestas fueron positivas y asumen como un hecho el regreso además de esgrimir como causa esencial su amor hacia los suyos. Esta percepción es muy importante en tanto desmiente y desmitifica las ideas que han asumido la inexistencia de una cultura nacional haitiana e incluso la idea de un concepto de nación en ese país para justificar los prejuicios y la discriminación hacia los inmigrantes.

\section{Algunas conclusiones comparativas}

En vistas de que nuestros objetivos fundamentales son los de determinar algunos de los principales cambios respecto a los resultados obtenidos hace más de una década en el estudio del fenómeno migratorio haitiano por parte de las Ciencias Sociales dominicanas, así como enmarcar 
el desenvolvimiento de algunas tendencias existentes para entonces y su repercusión en la actualidad, hemos resumido los principales resultados de nuestros trabajos de campo desde una perspectiva comparada. Para ello se han tomado como base los aspectos esenciales reseñados al inicio, y se han organizado los datos e informaciones actuales en referencia a su mantenimiento o transformación.

\section{Aspectos o tendencias aún vigentes}

1. La migración haitiana hacia la República Dominicana continúa vinculada con los momentos de crisis política y económica de ambas naciones y con la oferta laboral que genera el desequilibrio en el desarrollo capitalista. El peso de las relaciones históricas entre Haití y la República Dominicana, esencialmente complicadas y marcadas por la confrontación, continúan influyendo en el reforzamiento de las diferencias étnicas y en la visión opuesta que prevalece respecto a los inmigrantes haitianos.

2. El carácter fundamentalmente ilegal de la migración, al igual que en décadas anteriores, influye en la reducción del nivel de vida de los inmigrantes y a reducir los costos a los empleadores. En la nueva situación se observa la etnificación de un mayor número de labores a desarrollar por parte de los inmigrantes, lo que es un factor que agudiza aún más las contradicciones interétnicas.

3. En la actualidad la conservación de aspectos que definen la etnia de los inmigrantes haitianos al igual que hace unos años es palpable a través de cierta unidad de conciencia, en aspectos de orden social, cultural, lingüístico, religioso e incluso místico.

4. Entre los inmigrantes continúa siendo característico el bilingüismo, creole-español, resultado del contacto continuo con la sociedad dominicana. Sin embargo a pesar de que el creole es un elemento de identidad entre los inmigrantes, en ocasiones se percibe su negación como resultado de la condición de discriminado de este segmento de la población así como del hecho de estar sometida a prejuicios tanto raciales como de nacionalidad.

5. Los cambios étnicos y culturales que ha provocado la inmigración haitiana en la República Dominicana continúan siendo poco reconocidos por la mayor parte de la población, a pesar de l amplitud del intercambio y la convivencia étnica en los momentos actuales. 


\section{Aspectos que han sufrido transformaciones y nuevas tendencias}

1. El principal flujo migratorio haitiano ya no está remitido a la región sureste de la República Dominicana y a la influencia en esta zona de los principales ingenios azucareros Los estudios más recientes sobre la actual migración haitiana (Silié, et al, 2002) así como los resultados de nuestra investigación señalan que la situación migratoria con respecto a años anteriores se ha transformado. los trabajadores agrícolas, principalmente vinculados a la producción azucarera, han dejado de ser mayoría dentro de los inmigrantes en comparación con los que se dedican a otras actividades urbanas como la construcción, el turismo, las obras públicas y el comercio informal.

2. Los cambios en la nueva migración haitiana (Silié. et al, 2002) también están influidos por el sistema de contratación, y a pesar de que esta continúa con un carácter informal, las condiciones del inmigrante para negociar la misma le confieren mayores posibilidades en tanto este es libre de moverse a otras áreas de la producción o de los servicios.

3. A diferencia de los momentos anteriores la proporción de mujeres entre los nuevos inmigrantes ha aumentado, y se percibe un contacto mucho más fluido con el país de origen. lo que contribuye al mayor dinamismo del flujo migratorio, que muchas veces asume un carácter temporal.

4. A diferencia de la migración de braceros temporales haitianos que no establecía una influencia equilibrada en las relaciones entre las dos culturas, el nuevo tipo de inmigrante aunque posee mayores libertades para moverse de acuerdo ala oferta laboral, ya no significa un grupo de personas que sistemáticamente se trasladan de una región del país a otra de acuerdo a los ciclos impuestos por las labores agrícolas, sobre todo por la industria azucarera. sino que el hecho de ser una migración esencialmente hacia zonas urbanas y vinculada a actividades de otra naturaleza propicia una mayor interrelación cultural.

5. Las nuevas características de la migración haitiana se encuentran acompañadas de un renacimiento en los estereotipos de carácter cultural e histórico sobre la "amenaza haitiana" para la República Dominicana. Estos estereotipos entroncan con una percepción 
estrecha de la identidad nacional, en tanto conservar la identidad nacional significa evitar todo riesgo de contaminación racial o influencia cultural haitiana. La identidad dominicana dentro de esos estereotipos se construye sobre la base de la deculturación de la identidad haitiana. La expresión más claramente reciente es la obra de Manuel Núñez. El Ocaso de la Nación Dominicana.

6. La tendencia radicalmente opuesta a los estereotipos antihaitianos se fundamenta en el análisis de conceptos tan importantes como identidad, cultura, nacionalismo a lo largo de la historia Dominicana, así como en la contribución, ya sea empírica o teórica, a la reformulación de los mismos. Las investigaciones con esta perspectiva en el caso de los inmigrantes haitianos han privilegiado tanto los enfoques cualitativos como cuantitativos para incursionar en las vivencias de los individuos, sus percepciones de las relaciones sociales, su cultura, y el impacto en la cultura receptora.

7. A pesar de ello, la redefinición de la misma se hace imprescindible y es más evidente en una sociedad donde la ausencia de un entendimiento y aceptación común sobre sus costumbres y valores culturales han estimulado mayor rigidez respecto a estos. Ante esa situación los inmigrantes o han intentado asumir como estrategia aferrarse más a su cultura y establecer algunas condiciones que les permitan integrase como minoría, o asimilarse y aculturarse a la sociedad dominicana como una estrategia de supervivencia dentro de ella. Esta última es la más palpable en nuestras investigaciones.

8. Las repercusiones en el plano religioso de los estereotipos creados continuan presentando al inmigrante haitiano sumido en un océano de animismo y de creencias primitivas en las que no puede existir nada en común con el catolicismo prevaleciente en la religiosidad popular dominicana.

El hecho de que las prácticas de la religiosidad haitiana, en especial el vodú, se le considera una especie de brujería hostigada por el estado y por las religiones formales en la República Dominicana coincide con que la mayoría de la población de inmigrantes haitianos o de población dominicana de ascendencia haitiana plantea ser cristiana, sobre todo católica. La evidencia directa de este planteamiento fue arrojada por nuestro trabajo de campo en las localidades estudiadas. 
9. El análisis de los datos sobre actividades lúdicas evidencia una cierta contradicción con los datos sobre religiosidad. Una buena parte de los inmigrantes entrevistados negaron su asistencia a cualquier fiesta de carácter religioso (Gagá, Congo, Vodú), sin embargo en contradicción con esto y con la religión que dicen profesar, plantean la existencia de similitudes entre este tipo de ceremonias religiosas en República Dominicana y Haití. Ambos casos, tanto las informaciones sobre actividades lúdicas como sobre la religiosidad una estrategia, una posición ante la sociedad receptora y frente a su cultura. La estrategia es de ajuste, de acondicionamiento en función de situaciones determinadas

10. La situación de los inmigrantes, en especial hacia las zonas urbanas marca importantes diferencias en el aspecto de la vivienda que típicamente se había descrito para los inmigrantes haitianos en las zonas rurales o con respecto al barracón que fue la nota distintiva en cuanto a vivienda en el caso de los braceros azucareros. Se trata de viviendas alquiladas y no construidas por ellos, en el caso de los haitianos que se dedican a la actividad comercial, como la mayoría de nuestros entrevistados, al parecer disfrutan de mejores condiciones y mayores posibilidades económicas que el resto de los inmigrantes urbanos o rurales dedicados a otras actividades.

Los inmigrantes vinculados a sectores como la construcción, mayormente viven en casas de una sola pieza solos o con otros haitianos en los lugares de trabajo. Un elemento que refuerza las mejores condiciones del sector comerciante es el hecho de que la mayor parte de las viviendas fueron descritas como construidas de concreto, de zinc, madera y blocks, o de zinc y concreto.

11. Las entrevistas realizadas indican una simbiosis más acentuada de platos dominicanos y haitianos en el tipo de alimentación preferida por los nuevos inmigrantes. Las principales diferencias reconocidas continúan en el aspecto de la confección de los alimentos así como en el sazón, la mayor parte de los entrevistados coincide en una mayor condimentación de las comidas por parte de ellos, sobre todo el uso de picantes y otros productos naturales que refieren no emplearse o no existir en la República Dominicana La mayor dicotomía entre las preferencias de los inmigrantes y los patrones de la cultura receptora se encuentran en el aspecto de las bebidas. Aunque en su mayoría reconocen consumir o adaptarse al 
consumo de las bebidas dominicanas se observa una mayor variedad e incidencia en las bebidas típicas haitianas.

A diferencia de la investigación anterior en el plano de las comidas de orden religiosos o rituales vinculadas al vodú e percibió la negación sobre su conocimiento preparación o consumo, lo que coincide con la propia negación de estas prácticas por la mayoría de la población entrevistada.

12. Las enfermedades más comunes dentro de los inmigrantes están relacionadas con sus precarias condiciones de vida y el estado de hacinamiento y segregación a que están sometidos así como con las condiciones higiénicas de los lugares de habitación, Entre más comunes sobresalen las afecciones estomacales y las propias de países tropical.

La forma combatir las dolencias remite al empleo de los servicios de salud y hacia el uso de medios alternativos que van desde la automedicación hasta el empleo de remedios caseros. Entre los últimos, los más frecuentes son las infusiones o cocimientos de distintas hojas como el orégano, el limoncillo, limón, naranja, albahaca, cereza, etc, y su manera de prepararlo no difieren en gran medida de las formas de preparación tradicionalmente conocidas por la población dominicana.

13. Entre las principales dificultades para insertarse en la sociedad dominicana los inmigrantes señalaron los elementos de orden laboral, aspectos de orden jurídico, aspectos de orden cultural, elementos de orden sentimental, así como problemas de alimentación y salud. Los aspectos de mayor trascendencia fueron los de orden familiar y laboral además de los relacionados con el idioma.

14. Los cambios étnicos y culturales que ha generado la inmigración haitiana en la República Dominicana aunque continúan siendo poco reconocidos por la mayor parte de la población, ya no se circunscriben o son más perceptibles en determinadas regiones, sobre todo rurales o fronterizas, donde es intensa la convivencia, sino que el carácter continuo de esta inmigración y la intensidad de las influencias entre ambas etnias se ha extendido hacia las regiones urbanas y periféricas de las ciudades lo que ha dado lugar a un mayor dinamismo en las relaciones irterétnicas que incentiva la aparición de un nuevo grupo étnico con características propias y diferentes. 
Los inmigrantes entrevistados admitieron diferencias entra la cultura dominicana y haitiana, aunque en general las consideran muy próximas. En ellos también se percibe que la mayoría continúa identificando con su cultura de origen Los elementos en los que se admitieron las mayores similitudes están relacionados con las comidas, las personas, las viviendas, las fiestas, y en el aspecto religioso en tanto la mayoría se asume como católicos o evangélicos..

15. Las estrategias de evasión y a su vez de reafirmación étnica entre los inmigrantes estudiados se constataron en sus respuestas ante el cuestionamiento de asumir la ciudadanía dominicana así como en las razones argumentadas para un posible regreso ante un cambio de la situación haitiana Esta percepción es importante en tanto desmiente y desmitifica las ideas que han asumido la inexistencia de una cultura nacional haitiana e incluso la idea de un concepto de nación en ese país para justificar los prejuicios y la discriminación hacia sus inmigrantes.

\section{Bibliografía}

Andujar, Carlos. "Sexualidad y religiosidad popular en los bateyes de República Dominicana" en Ecos, Órgano del Instituto de Historia de la Universidad Autónoma de Santo Domingo. Año IV No. 5 1996, p. 201

Balaguer. Joaquín. Memorias de un cortesano de la era de Trujillo, Editora Corripio, 1988

Bissainthe, Jean Ghasmann. Paradigma de la Migración Haitiana en República Dominicana. Instituto Tecnológico de Santo Domingo. República Dominicana, 2002

Bridget Wooding y Richard Mosely. Inmigrantes haitianos y dominicanos de ascendencia haitiana en la Republica Dominicana. Publicación de la Cooperación Internacional para el Desarrollo (CID) y el Servicio jesuita a Refugiados y Migrantes. Santo Domingo, 2004.

Esteban Deive. Carlos. Vodí y Magia en Santo Domingo. Ediciones del Museo del Hombre Dominicano, Santo domingo, 1979.

Duarte, Isis y André Corten. Quinientos mil haitianos en República Dominicana en Estudios Sociales. Número 98, Octubre -Diciembre, 1994. Editora Amigos del Hogar, Santo Domingo. República Dominicana. Vol XXVII

Dore, Carlos "Estudios sobre el estado del Arte" en Encuesta sobre inmigrantes Haitianos en República Dominicana. Facultad Latinoamericana de Ciencias 
Sociales. Ediciones FLACSO-OIM, Santo Domingo. República Dominicana, 2004.

Encuesta sobre inmigrantes haitianos en República Dominicana publicada por la OIM y la FLACSO en el 2004.

Ferran. Fernando. Presencia haitiana en República Dominicana en Revista Ciencia y Sociedad. Vol XI, número 4. Octubre-Diciembre. 1986

García Arévalo, Manuel, Fermín Álvarez Santana y otros. Presencia Étnica en San Pedro de Macorís. Serie XXX aniversario de la UCE. Editora de Colores SA, Santo Domingo, 2000.

Ibarra. Jorge. "El despertar de la conciencia nacional en Cuba. Santo Domingo y Puerto Rico" en Del Caribe No.42. Casa del Caribe, Santiago de Cuba, 2003.

El otro del nosotros. Informe de Investigción acerca del prejuicio antihaitiano en la ciudad de Santiago, de la República Dominicana; un aporte a la comprension y al acercamiento de dos pueblos.

Ortega. Elpidio. Expresiones culturales del Sur. Publicaciones de la Academia de Ciencias de la República Dominicana, Santo Domingo, República Dominicana, 2000 .

Peña Batlle. Manuel Arturo. Los origenes del Estado Haitiano. Ciudad Trujillo, Montalvo, 1954.

Peña Batlle. Manuel Arturo. Historia de la cuestión fronteriza dominico-haitiana, Ciudad Trujillo, Luis Sánchez Días. Casa Editora. 1946.

La Actitud Racial en la República Dominicana, Publicación del Servicio Jesuita de Refugiados y Migrantes (SJRM), Santo Domingo, República Dominicana. Octubre 2004.

Mateo. Andrés L. "Prólogo a la obra de Jean Price Mars en Así habló el tio". Serie Literatura caribeña. Colección la otra orilla. Editora Manatí, Santo Domingo. 2000 .

Nyberg, Ninna. "Género, etnicidad y cruce de fronteras: ¿cambios en la identidad genérica dominicana? en Estudios Sociales Año XX. No 109, 1997.

Núñez, Manuel. El ocaso de la Nación Dominicana. Editora Letra gráfica, santo Domingo, República Dominicana, 2001.

Peña Batlle. Manuel Arturo. Historia de la cuestión fronteriza dominico-haitiana. Casa editora de Luis Sánchez Andujar. Ciudad Trujillo, 1946.

Peña Batlle. Manuel Arturo. Los origenes del estado haitiano. Editora Montalvo, Ciudad Trujillo, 1954. 
Pérez, Odalís. Nacionalismo y Cultura en República Dominicana. Editora Manatí, Santo Domingo, República Dominicana

Presencia africana en la cultura dominicana. Centro Cultural español, Santo Domingo, República Dominicana, Octubre, 1997.

Price Mars, Jean. Así habló el tío. Serie literatura caribeña. Colección la otra orilla, Editora Manatí, Santo Domingo, 2000.

Resumen Ejecutivo, bateyes del Estado. Encuesta socioeconómica y de salud de la población materno- infantil.

Rosario, Reina. "Algunos aspectos etnodemográficos de la migración haitiana a República Dominicana”. Trabajo presentado para aspirar al grado de maestría en la Universidad de Lomonosov, mecanuscrito ilustrado. Moscú, 1989.

Rosemberg, June. El Gagá, Religión y Sociedad de una culto dominicano, Santo Domingo editora de la UASD, 1979.

Silié, Rubén “Aspectos socio-históricos sobre la inmigración haitiana República Dominicana” en Eevista general de la Universidad Nacional Pedro Henríquez Ureña. Enero-Diciembre, 1996.

Silié, Rubén. Carlos Segura y Carlos Dore Cabral. La nueva inmigración haitiana. FLACSO, República Dominicana, 2002.

Ubiñas, Guaroa. Historias y levendas Afro-Dominicanas. Editora Manatí, Santo Domingo, 2003.

Vargas, Tahira. "Levantamiento Documental: La situación Dominico-Haitiana" en Estudios Sociales. Número 98, Octubre -Diciembre, 1994. Editora Amigos del Hogar, Santo Domingo, República Dominicana. Vol XXVII.

Vega, Bernado. "Etnicidad y el futuro de las relaciones Dominico-Haitianas" en Estudios Sociales. Año XXVI, número 94, octubre-diciembre, 1993. 


\section{Anexo}

Anexo: Gráficos ilustrativos de los resultados estadísticos de las entrevistas realizadas en el batey de Palavé y en el Pequeño Haití.

\section{Mercado}
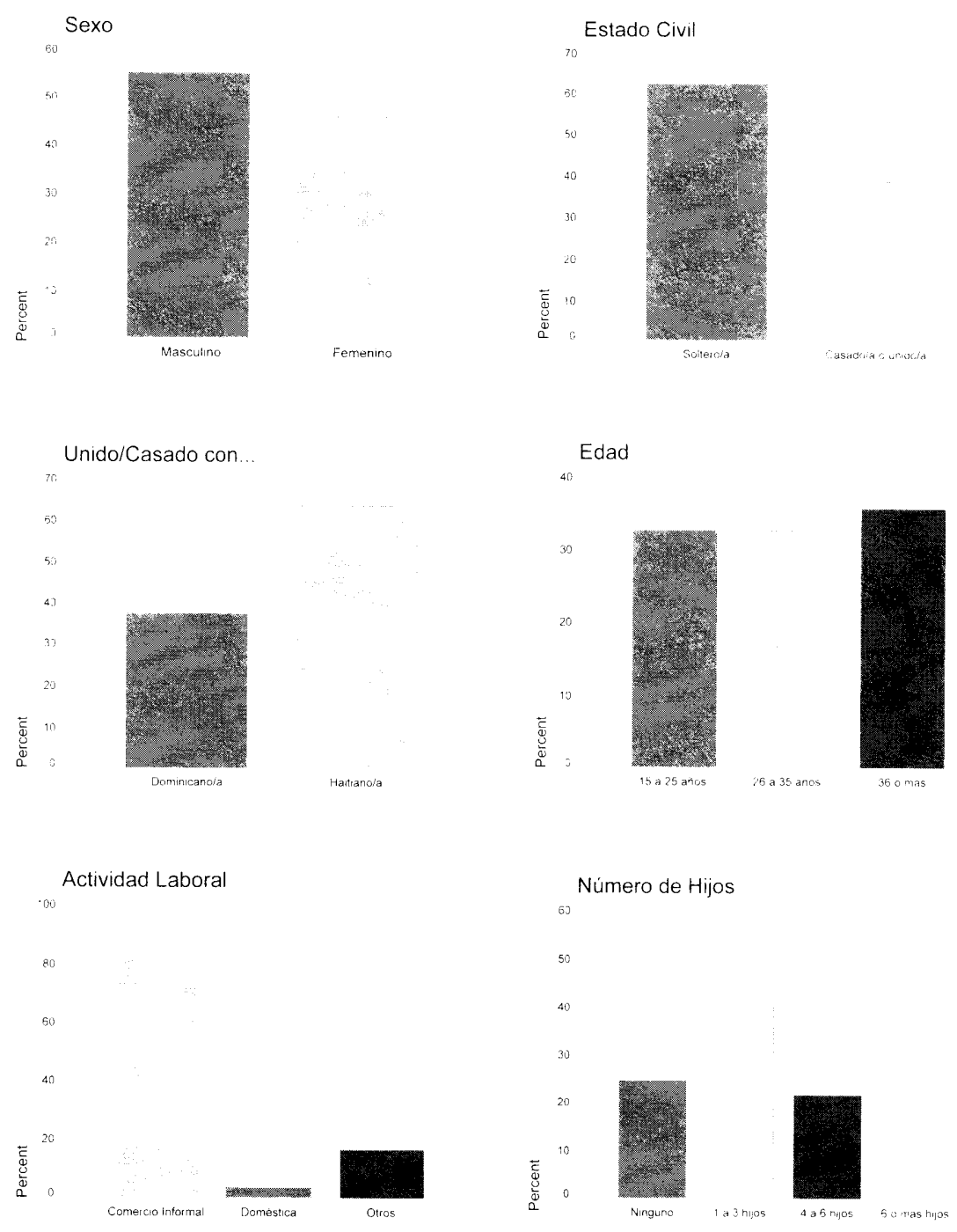
Reina Rosario y Jorge Ulloa: Algunos aspectos socioculturales de la inmigración...
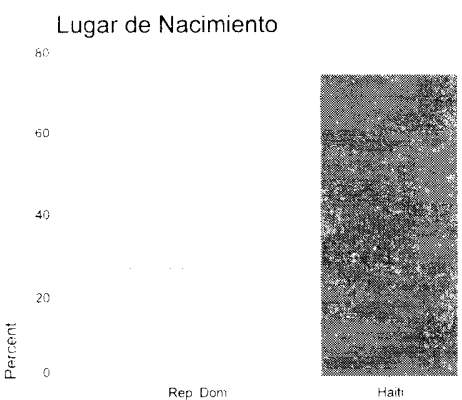

¿Sus padres son haitianos?

Tiempo residiendo en RD
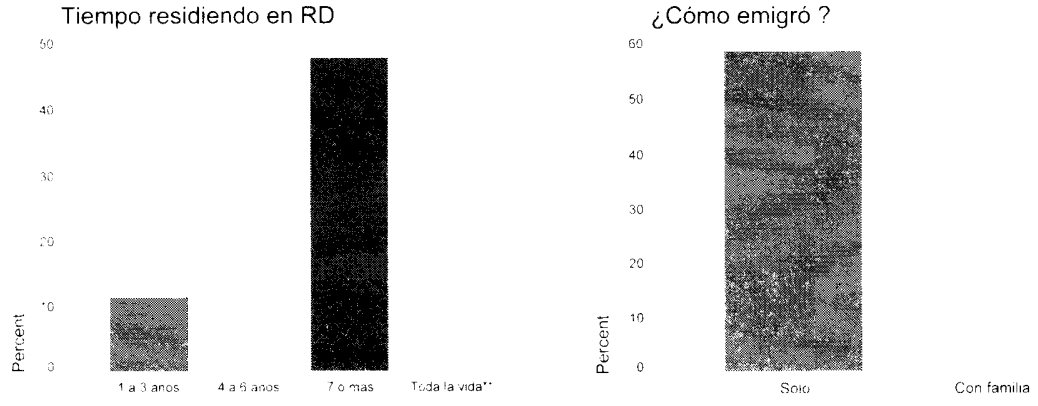

¿Siempre ha residido aqui?
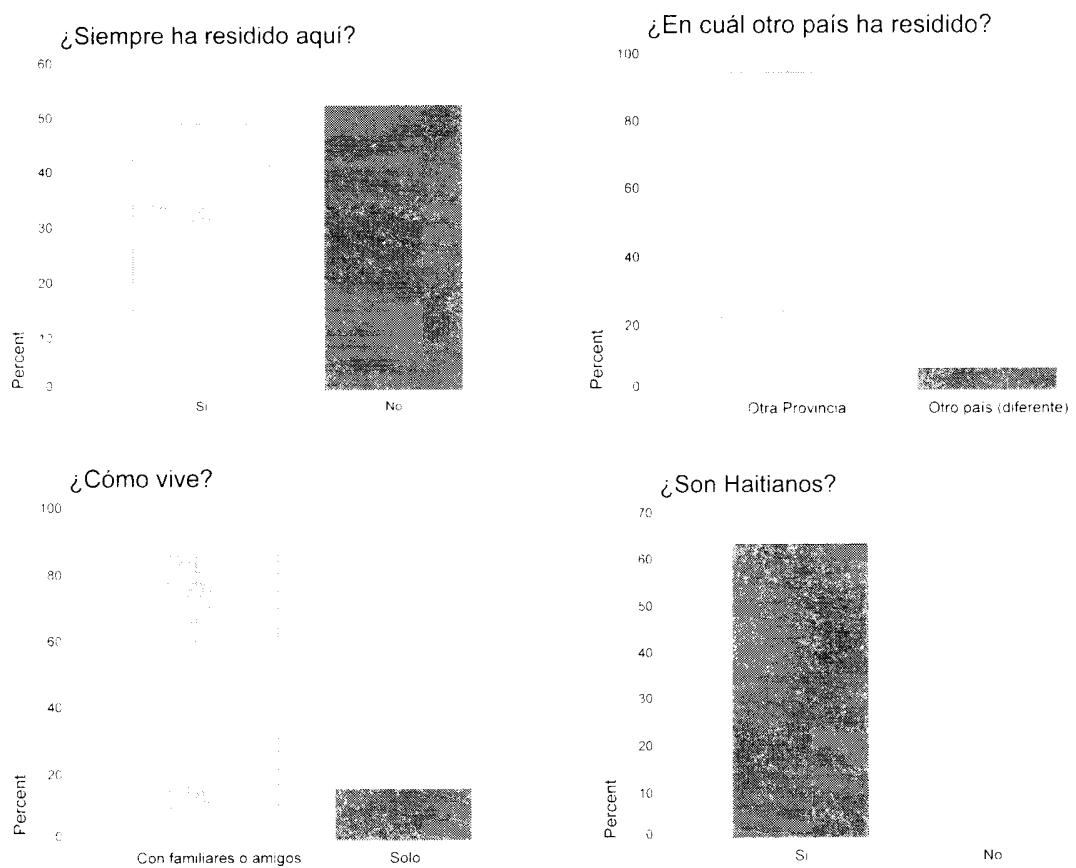

114 
¿El lugar donde viven lo construyeron uds?
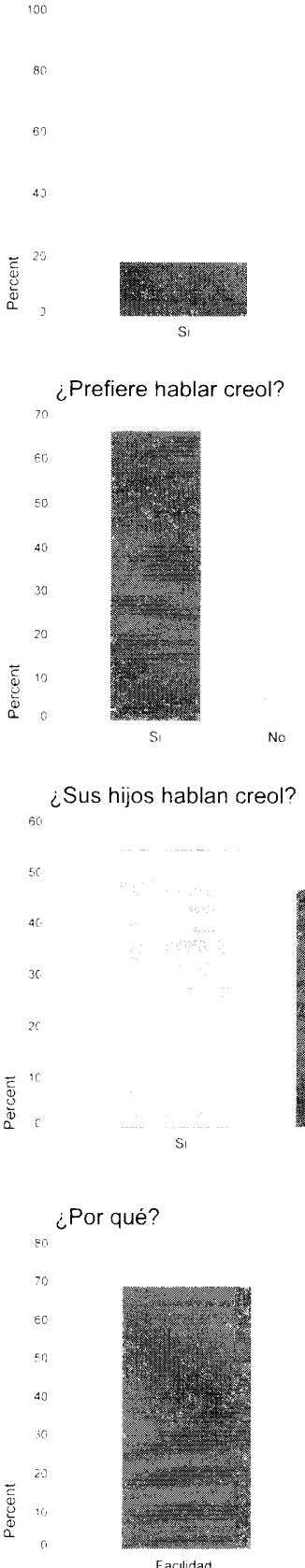
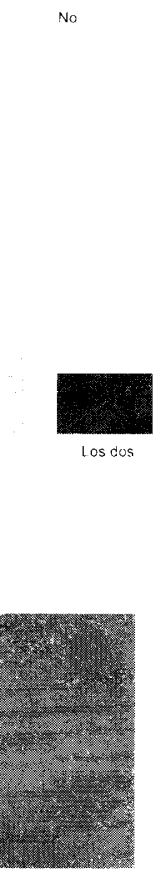

No
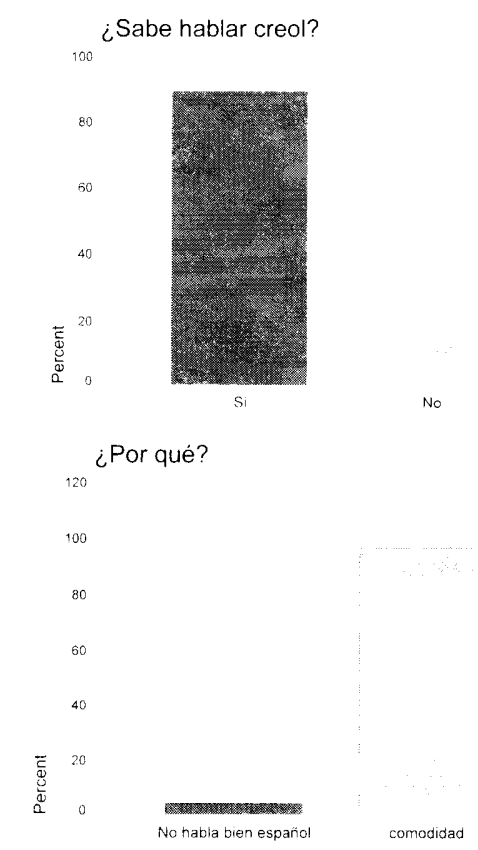

¿Se preocupa para que sus hijos lo aprendan(creol)?

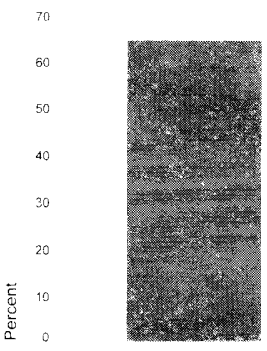

¿Le gusta beber?

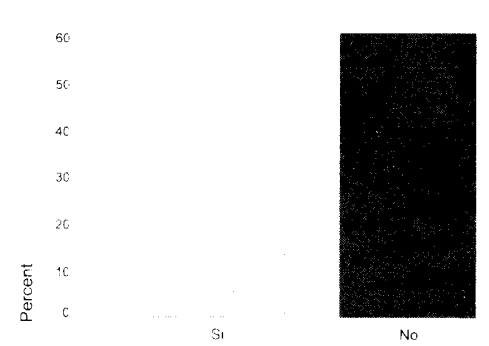


Reina Roserio 1. Jorge Ulloa: Algunos aspectos socioculturales de la inmigración...

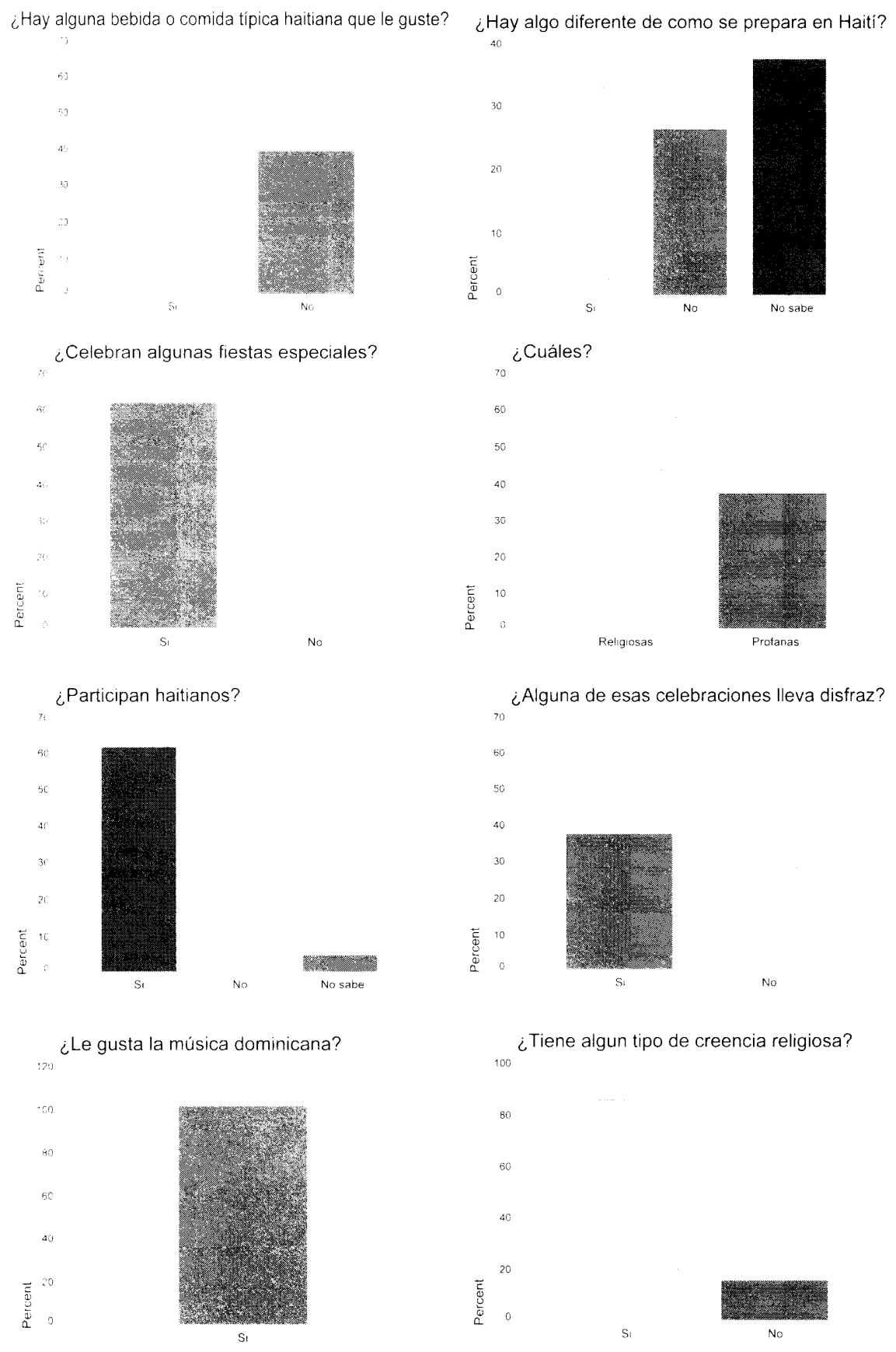

116 


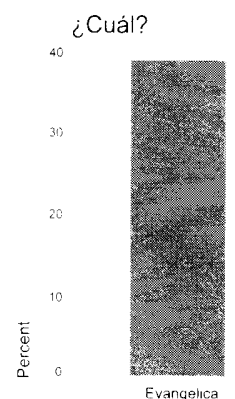

¿Siempre ha tenido esa creencia religiosa?

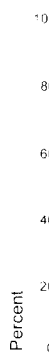

80

60

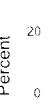

Si
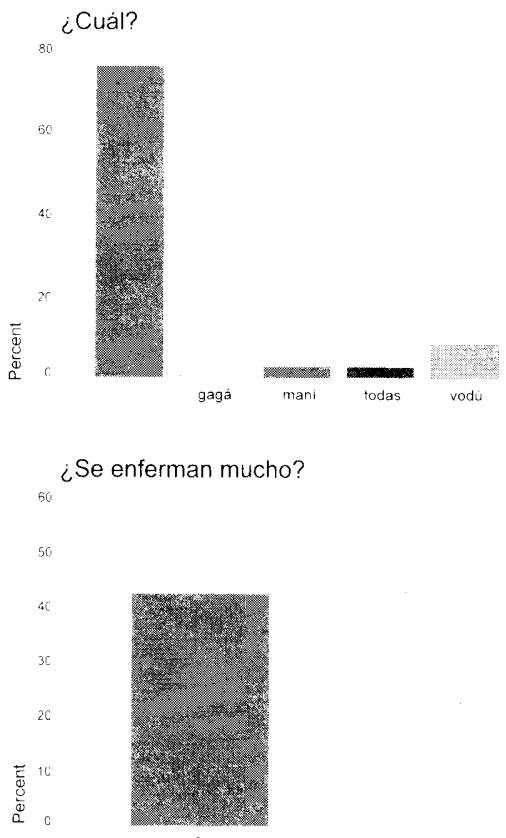

¿Asiste a alguna iglesia?

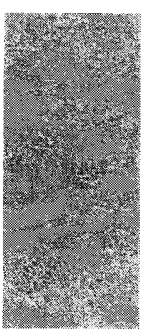

No

¿Asiste a alguna actividad de Gagá, vodú, mani ...?

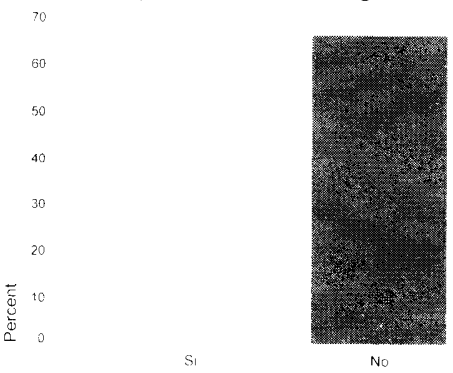

¿Qué opina de esas fiestas?

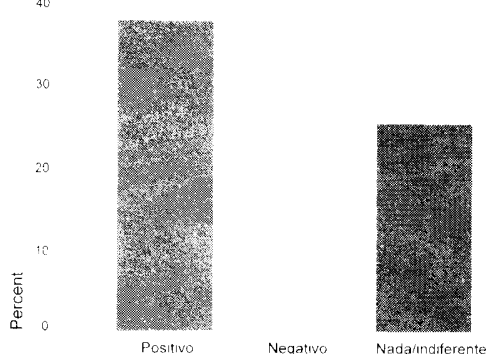

¿Qué medios emplean para curar sus malestares?

60
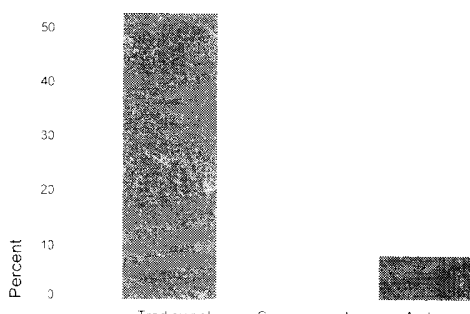
Reina Rosario y Jorge Ulloa: Algunos aspectos socioculturales de la inmigración...
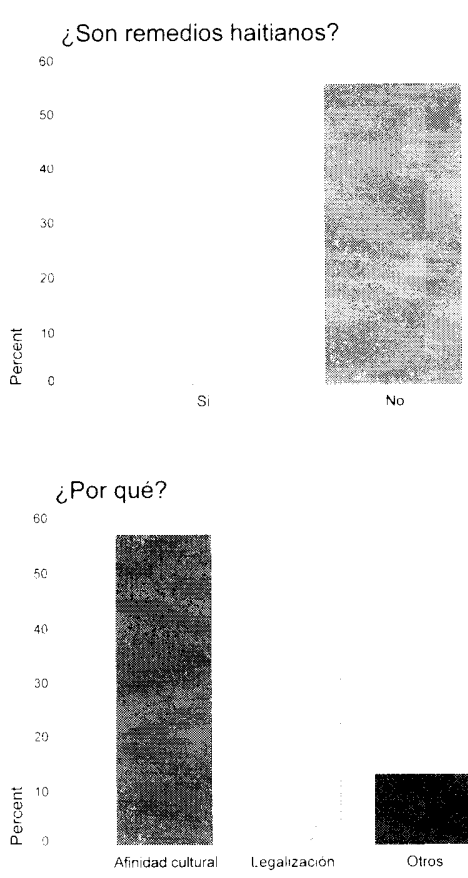

¿Qué ha sido lo más dificil después que salió de haiti?

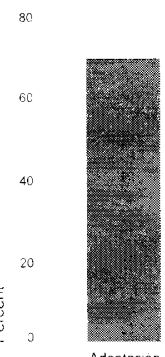

Adaptacion Discrimunación Empleo

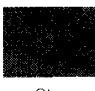

Otros

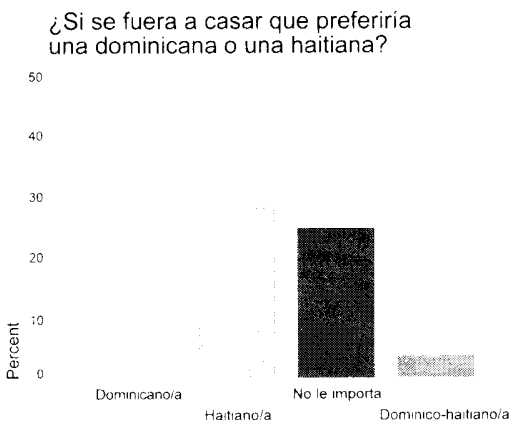

¿Si tuviera la oportunidad de casarse con un dominicano lo haria?

${ }_{150}^{150}$

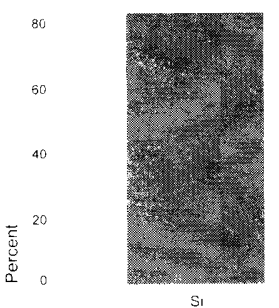

¿RD y Haiti se parecen?

$$
\begin{gathered}
7 \\
\\
\\
\\
\end{gathered}
$$

¿Si la situación de Haiti cambiara regresaría?

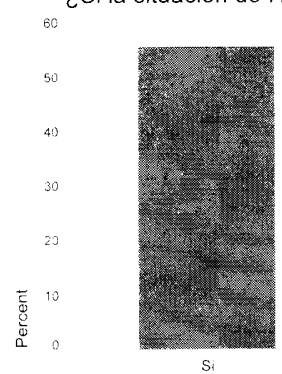




\section{Palave}

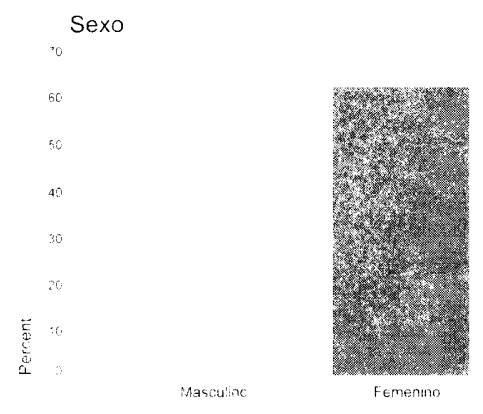

Estado Civil

Unido/Casado con

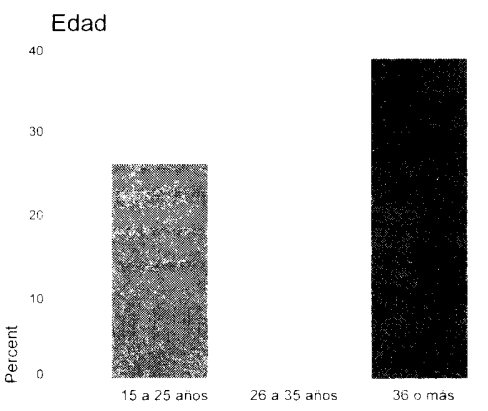

Actividad Laboral

Número de Hijos
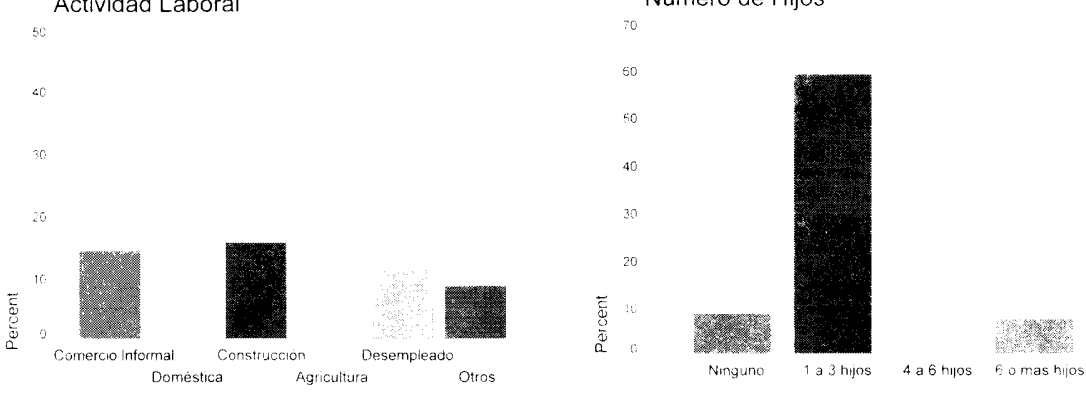
Reina Rosario 1. Jorge Ulloa: Algunos aspectos socioculturales de la inmigración...

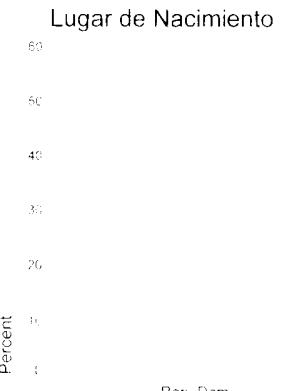

Tiempo residiendo en RD
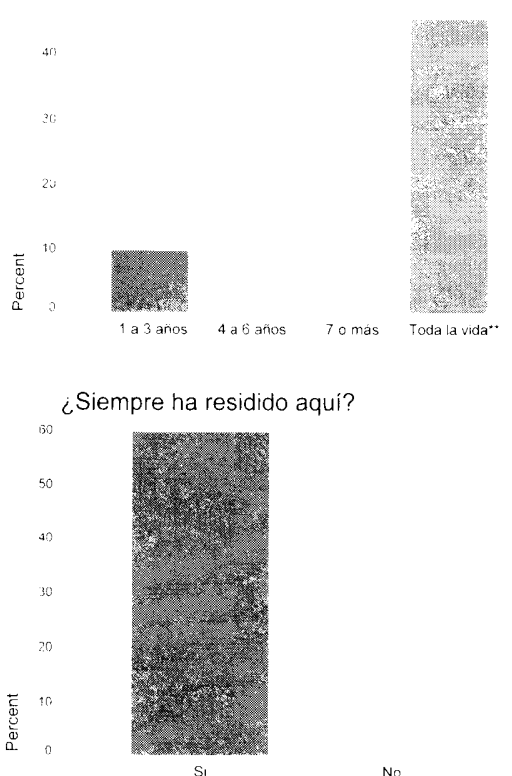

¿Cómo vive?

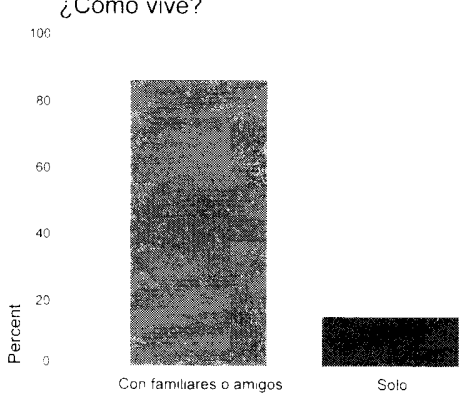

120
¿Sus padres son haitianos?

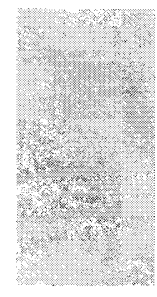

Hati:

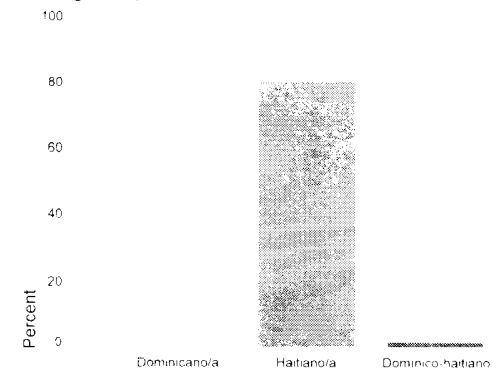

¿Cómo emigró?

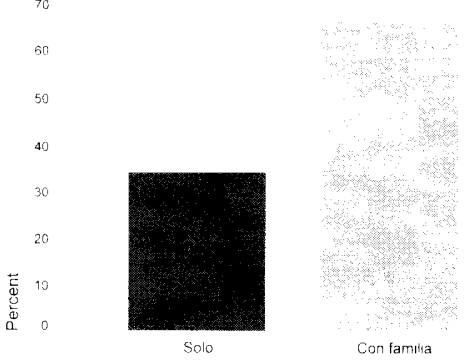

¿En cuál otro pais ha residido?

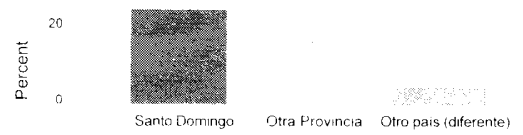

¿Son Haitianos?

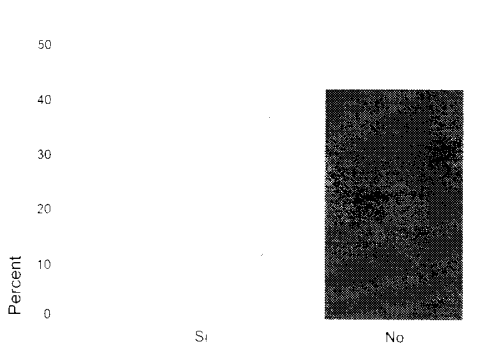


Ciencia y Sociedad, Vol XXXI, núm 1, 2006, 64-124

¿El lugar donde viven lo construyeron uds.?

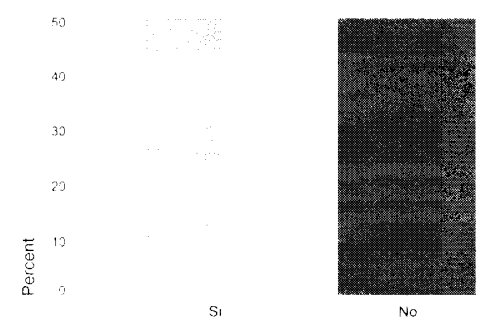

¿Prefiere hablar creol?

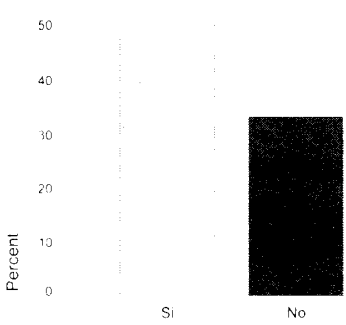

¿Sus hijos hablan creol?
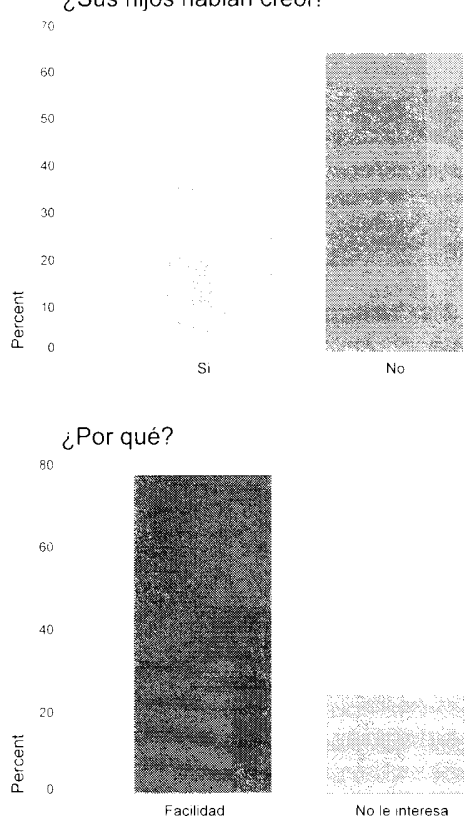

¿Sabe hablar creol?

100

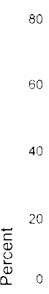

¿Por qué?

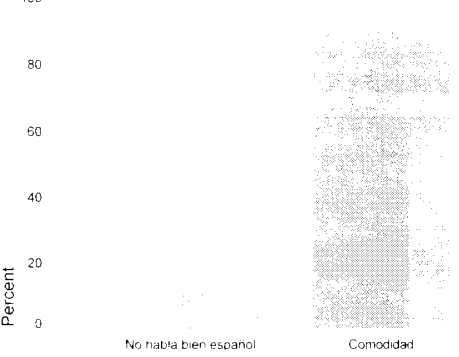

¿Se preocupa para que sus hijos lo aprendan(creol)?

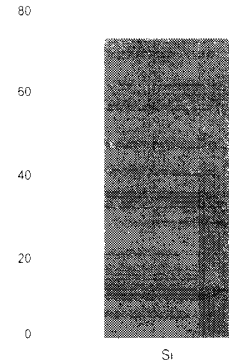

Hay alguna bebida o comida típica haitiana que le guste?

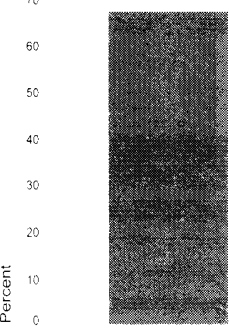


Reina Rosario y Jorge Ulloa: Algunos aspectos socioculturales de la inmigración...
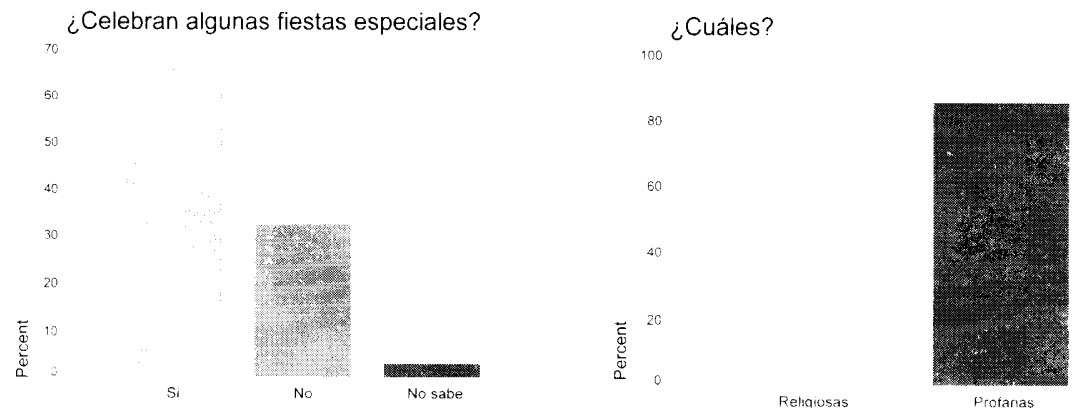
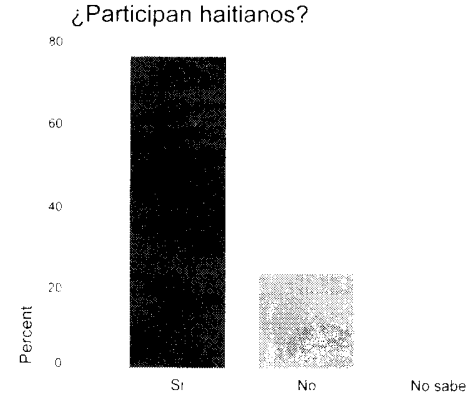

¿Le gusta la música dominicana?
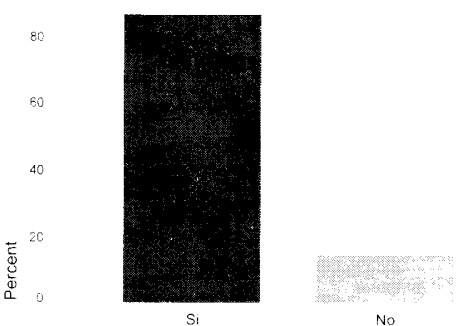

No

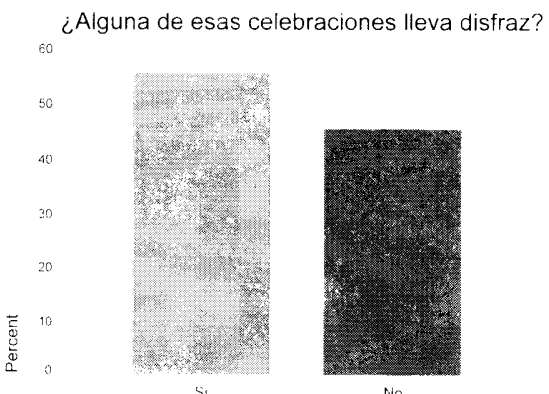

¿Tiene algun tipo de creencia religiosa?

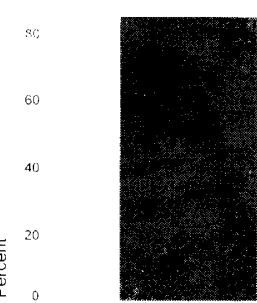

¿Asiste a alguna iglesia?

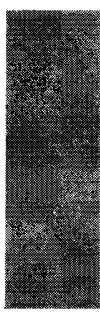

Otras

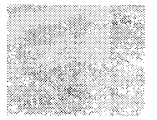

No 


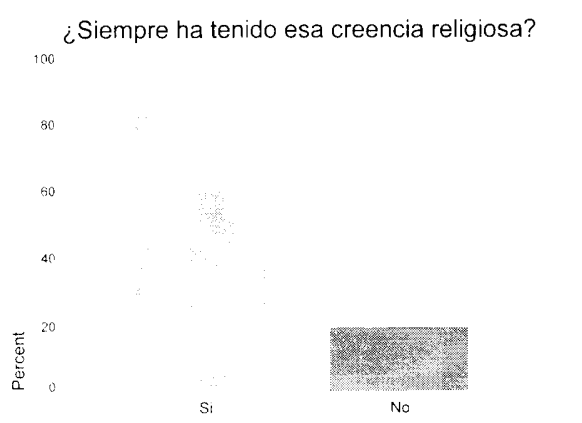

¿Asiste a alguna actividad de Gagá, vodú, mani...?

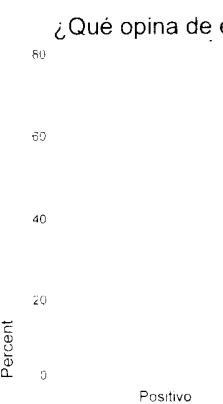

esas fiestas?
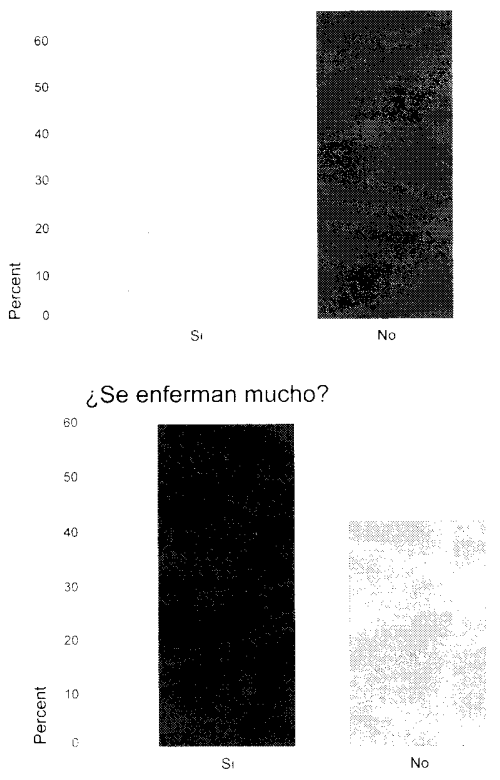

¿Qué medios emplean para curar sus malestares? ¿Son remedios haitianos?

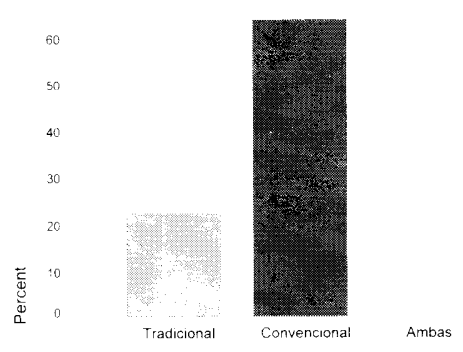

100

¿Si se fuera a casar que preferiria una dominicana o una haitiana?
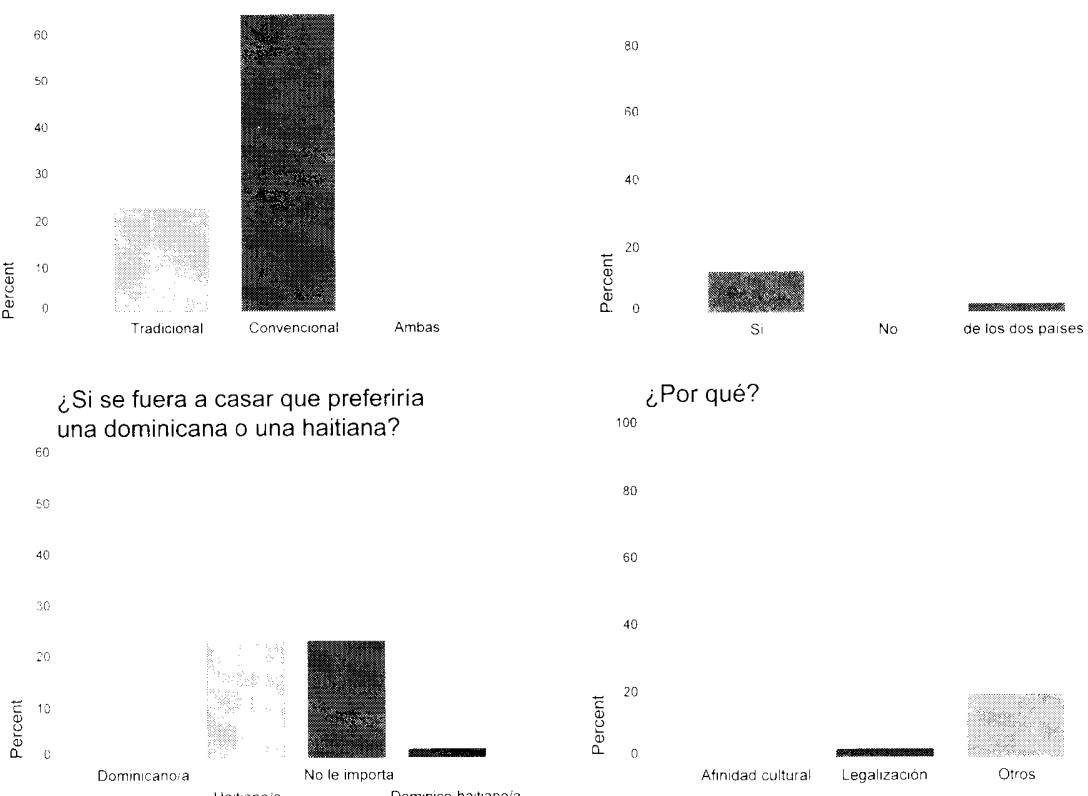
Reina Rosario y. Jorge Ulloa: Algunos aspectos socioculturales de la inmigración...

¿Si tuviera la oportunidad de hacerse

ciudadano dominicano lo haria?

$$
+20
$$$$
100
$$

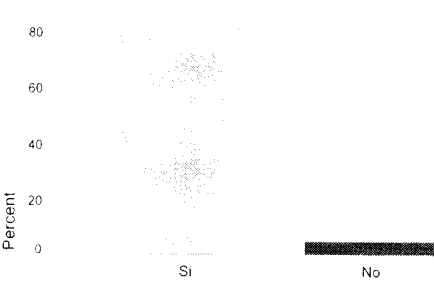

¿RD y Haití se parecen?

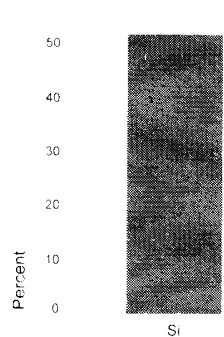

No
¿Qué ha sido lo más dificil después que salió de haiti?

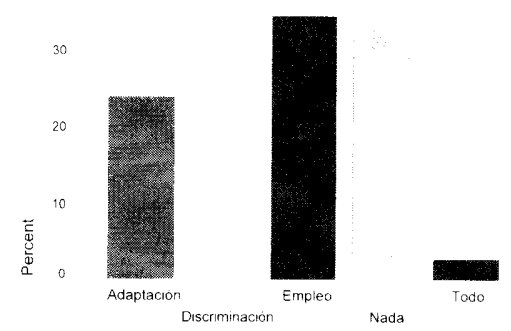

¿Si la situación de Haití cambiara regresaria?

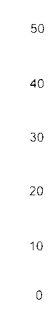

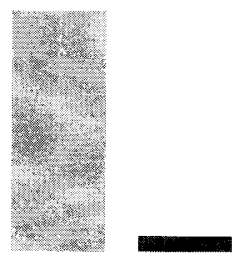

